\title{
Sweet Diversity: Colonial Goods and the Rise of European Living Standards after $1492^{*}$
}

\author{
Jonathan Hersh \\ University of Pennsylvania - The \\ Wharton School
}

\author{
Hans-Joachim Voth \\ UPF and CREI, Barcelona
}

\begin{abstract}
Did living standards stagnate before the Industrial Revolution? Traditional real-wage indices typically show broadly constant living standards before 1800 . In this paper, we show that living standards rose substantially, but surreptitiously because of the growing availability of new goods. Colonial luxuries such as tea, coffee, and sugar transformed European diets after the discovery of America and the rounding of the Cape of Good Hope. These goods became household items in many countries by the end of the $18^{\text {th }}$ century. We use the Greenwood-Kopecky (2009) method to calculate welfare gains based on data about price changes and the rate of adoption of new colonial goods. Our results suggest that by 1850, the average Englishman would have been willing to forego $15 \%$ or more of his income in order to maintain access to sugar and tea alone. These findings are robust to a wide range of alternative assumptions, data series, and valuation methods.
\end{abstract}

JEL: D12, D60, F10, N33

Keywords: Economics of New Goods, Age of Discovery, Consumption, Early Modern Europe, Living Standards.

\footnotetext{
* Angus Deaton inspired the authors to work on the topic. We thank Karen Kopecky for help with the estimation procedure, Joel Mokyr and Emily Oster for feedback and advice, and Ryan Wang for outstanding research assistance. Seminar audiences at Chicago, Northwestern University and UPF provided helpful feedback. We thank Chiaki Moriguchi, Albert Carreras, and Jeremy Greenwood for their comments.
} 


\section{Introduction}

By 1800, Europeans could see the Age of Discovery's impact everywhere. Spices from Asia added flavor to meals; tomatoes transformed Mediterranean diets; and potatoes provided a new and cheap source of calories. Silver originally imported from the Americas was used for coins, serving as a medium of exchange for purchases all over the continent. Salted cod from Newfoundland arrived on European tables by the boatload. European fleets and armies fought each other in the furthest corners of the earth in a struggle for global supremacy. Many scholars thus concluded that globalization began in 1492 (Bentley 1999).

At the same time, the Age of Discovery apparently did not affect European living standards, according to the dominant view in the literature. Profits from trade with the Americas were far too small to influence the transition to self-sustaining growth (O'Brien 1982, Engerman 1972), and overseas trade did not change factor prices decisively before the 1830s (O’Rourke and Williamson 2002). ${ }^{1}$ The world economy remained poorly integrated until 1800 (Menard 1991). Nunn and Qian (2008) conclude that the introduction of the potato increased agricultural productivity and lead to higher urbanization rates. They do not argue that its introduction improved living standards. ${ }^{2}$ The supply of raw materials from the New World was also unimportant (Clark, O’Rourke, and Taylor 2008). Thus, Europeans lived none the better as a result of the discoveries.

In this paper, we argue that the New World improved European living standards directly and importantly through gains from new goods. Global trade after 1500 mattered not because the quantities involved were large, but because of the nature of the goods traded. The discoveries made life better by offering access to sugar, tea, chocolate, tobacco, and coffee. Aggregate consumption of these colonial luxuries grew rapidly during the early modern period. Starting either from zero (for tea, tobacco, and coffee) or from very low levels of consumption (sugar), English imports per head surged to 23 pounds of sugar, almost 2 pounds of tea, 1 pound of tobacco, and 0.1 pound of coffee by 1804-06. ${ }^{3}$ The rise of hot, sweetened beverages transformed meals and forms of social interaction (Braudel 1988, Cowan 2005).

\footnotetext{
${ }^{1}$ One exception is Acemoglu, Johnson, and Robinson (2005), who emphasize the indirect consequences of profits from Atlantic trade, leading to greater constraints on the executive in Europe.

${ }^{2}$ Potato consumption may not have improved the quality of life by much - consumers remained sceptical of its appeal for a long time, and only ate it when no other source of calories was available (Schivelbusch 1992).
} 
Breakfast changed beyond all recognition. Taking a hot, caffeinated drink in company became an established form of social interaction.

Gains in consumer welfare from the arrival of new overseas goods have largely been ignored. This is because long run changes in living standards have mainly been explored through real wage indices using an unchanging consumption basket. ${ }^{4}$ Focusing on England from 1600 to 1850, we use detailed historical data on the price and consumption of increasingly affordable colonial goods to estimate welfare gains from their introduction. To put a value on tea, sugar, and coffee in early modern consumption baskets, we use standard economic techniques that have been developed for analysing the utility gains of new products, from Apple Cinnamon Cheerios to minivans and computers. ${ }^{5}$ We begin with an examination of historical data on prices and consumption shares of new goods. Adopting a model for the value of new goods (Greenwood and Kopecky 2009), we derive welfare gains from a calibration exercise. The results suggest that by 1850, Englishmen's welfare had increased by at least 15 percent as a result of the availability of these goods alone. Other colonial luxuries such as chocolate, spices, and tobacco probably increased consumer welfare even more. These findings provide further evidence for the welfareenhancing effects of trade arising from greater variety, as highlighted recently by Broda and Weinstein (2006). ${ }^{6}$

Contemporaries noticed how important new colonial luxuries were for rich and poor. In 1797, Sir Frederick Eden described how "in the South of England, the poorest labourers are habituated to the unvarying meal of dry bread and cheese...: and in those families, whose finances do not allow them the indulgence of malt liquor, the deleterious produce of China [tea] constitutes their most usual and general beverage. [...] In poor families, tea is not only the usual beverage in the morning and evening, but is generally drank [sic] in large quantities even at dinner.” (Eden 1797). During the 1790s, a period of unusually high prices and severe downward pressure on lowerclass living standards, as much as seven percent of household income-and roughly

\footnotetext{
${ }^{3}$ Mokyr (1988).

${ }^{4}$ Phelps-Brown and Hopkins (1981), Allen (2001). Clark (2005) uses a changing consumption basket but new goods such as tea are added at a late stage of adoption.

${ }^{5}$ Hausman (1996); Bresnahan (1996); Greenwood and Kopecky (2007); Petrin (2002).

${ }^{6}$ They recently investigated the issue empirically, and concluded that between 1970 and 2000, variety growth alone added 3 percent to US real income. Feenstra (1994) and Romer (1994) had earlier suggested that trade liberalizations may be welfare enhancing because they raise the range of goods available.
} 
$10 \%$ of a household's food budget - was spent on tea, coffee, sugar and treacle by poor, working-class households. ${ }^{7}$ This illustrates the high value assigned to these new commodities, despite economic stress.

Incorporating the value of variety in welfare analysis has a long tradition in economics (Hotelling 1929, Lancaster 1975). In models of consumer choice in the Dixit and Stiglitz (1977) and Spence (1976) tradition, variety adds directly to consumer welfare. Models of the Dixit-Stiglitz-Spence type are widely used in international trade, macroeconomics, and economic geography. However, the majority of papers examining living standards over the long run focus on an unchanging basket of goods (Allen 2001, Phelps-Brown and Hopkins 1981). This shortcoming is likely to be problematic when consumption habits change dramatically. If expanded choice was one of the New World's main contributions to living standards in the Old, standard measures of purchasing power will fail to capture the true change in welfare. By the time of the Industrial Revolution already, diets had been transformed by the arrival of new goods and the declining costs of once exclusive luxuries. As a result, we argue, overseas expansion had a markedly larger impact on European living standards than previously thought. ${ }^{9}$

Our findings contribute to the literature examining the value of increased variety and of new goods. Because the calculation of welfare gains from new goods is not straightforward, a variety of methods have been used and applied in recent years. ${ }^{10}$ Some follow the work by Hausman (1996) who estimated that the introduction of Apple-Cinnamon Cheerios increased welfare by the equivalent of $0.002 \%$ of 1992 consumption expenditure. ${ }^{11}$ More recently, scholars have estimated gains from the introduction of the minivan (Petrin 2002), online booksellers (Brynjolfsson et al. 2003), the internet (Goolsbee and Klenow 2006), and satellite TV

\footnotetext{
${ }^{7}$ Feinstein 1998, table 1. Sugar and treacle absorbed 7\%, and tea and coffee another 3\%. Horrell (1996) gives a slightly lower figure for working-class households in the 1790s (6.2\% of total expenditure).

${ }^{9}$ O'Rourke and Williamson (2002) argue that "the only irrefutable evidence that globalisation is taking place is a decline in the international dispersion of commodity prices or what might be called commodity price convergence”. We contend that for globalization to matter, global trade should affect living standards significantly. It can do so in one of two ways - through changes in quantities (with an associated change in prices), or through the value of variety.

${ }^{10}$ See Bresnahan and Gordon (1996).

${ }^{11}$ Cf. the comment by Bresnahan (1997).
} 
(Goolsbee and Petrin 2004). These methods typically rely on household level data for adoption rates and price variation across consumers. Data requirements are exacting. The same is true of the method used by Broda and Weinstein (2006), who show how expanding variety as a result of more trade after 1970 raised US living standards.

Greenwood and Kopecky (2009) introduce a method that makes less stringent demands of the data. Their approach is more macroeconomic, and requires aggregate data on prices and take-up rates of a new consumption item. For working with historical data, this is an advantage. That is why we use their method. Data on the characteristics of consumers, as well as take-up rates, as required for analysis in the style of Berry et al. (1995), is not readily available in our setting. In particular, panel data on consumption patterns is conspicuous by its absence. ${ }^{12}$ Greenwood and Kopecky use a modified model of consumer demand where initial marginal utility of new good consumption is bounded, allowing gains in consumer surplus to be calculated. Increases in welfare are calculated as moving from an initial state with an infinite new good price to a state with observed prices and consumption. The authors find welfare gains from the introduction of personal computers up to $4 \%$ of consumption expenditure.

Other related literature includes papers in unified growth, as well as papers on the historical significance of 1492. Adam Smith called the discovery of America and Vasco da Gama's rounding of the Cape of Good Hope "the two most important events in recorded history.” Scholars like Bentley (1999) and Frank (1998) agreed with the proposition, arguing that a worldwide trading system emerged quickly. Wallerstein (1974) concluded that a Europe-centric mode of capitalist production emerged from the $16^{\text {th }}$ century onwards. These papers are at variance with contributions in the economic history literature arguing that the overall impact of the discoveries as negligible.

Unified growth papers such as Kremer (1993), Galor and Weil (2000), Jones (2001), and Hansen and Prescott (2002) emphasize the transition from millennia of stagnation to rapid growth. That a period of gradual acceleration preceded "take-off" is central to the model in Galor and Moav (2002), and has been explored in terms of implications for the cross-section of economic growth (Voigtlaender and Voth 2006).

\footnotetext{
${ }^{12}$ For some years, there is some scattered data on cross-sectional consumption, at least for some of our goods. Yet the principal source of variation is over time. Here, data available on consumer characteristics vary over time at a much lower frequency than prices and quantities do.
} 
However, there is disagreement about the extent to which living standards remained broadly constant before 1800. Nordhaus (1996) examines the history of lighting to suggest that cost of living indices have vastly underestimated the decline in the cost of many goods over the last 200 years. ${ }^{13}$

We proceed as follows. First, we discuss the historical background and context - how did sugar and tea, coffee and tobacco enter European consumption? In section III, we discuss our data sources. Section IV presents our methodology and main findings. In section $\mathrm{V}$, we examine the robustness of our findings to alternative data sources and calibration assumptions, as well as alternative methods of calculating the value of new goods. Section V concludes.

\section{Historical Background and Context}

In this section, we summarize the existing literature on living standards over the long run. We also describe how sugar, tea, coffee and tobacco became items of mass consumption in Europe.

\section{Living standards in England before 1850}

Measures of per capita income and of living standards broadly suggest stagnation until 1800. ${ }^{14}$ Figure 1 presents two real wage series for the period of this study, one by Phelps-Brown and Hopkins (1981) and a more recent series by Clark (2005). Phelps-Brown and Hopkins used a Laspeyres index for the seven centuries covered by their index, with a weight of $70 \%$ for food. Their results suggest that Englishmen saw their living standards surge by almost 200\% after the Black Death in the middle of the fourteenth century. After 1500, a long period of decline set in. By 1600, much of the gain in living standards from the plague had disappeared. The $17^{\text {th }}$ and $18^{\text {th }}$ centuries then saw a recovery. Nonetheless, by 1800 , living standards were still $25 \%-50 \%$ lower than they had been in 1450. Loschky (1980) reworked the Phelps-Brown and Hopkins series, using Paasche and chain weighted price indices. His findings are markedly more optimistic, showing a less-marked decline during the early modern period. This is mainly due to changes in the relative price of manufactured goods,

\footnotetext{
${ }^{13}$ Hulten (1996) questions the plausibility of Nordhaus's result.

${ }^{14}$ According to Maddison (2001), English GDP per capita rose at a rate of less than $0.3 \%$ between 1500 and 1700.
} 
which became cheaper. For example, his Paasche index recovers its post-Plague peak by the middle of the $18^{\text {th }}$ century, a full 100 years before the date given by PhelpsBrown and Hopkins.

Clark (2005) offers a new, improved real wage index, drawing on a host of additional information. He changed both the wage series and price index. His expenditure weights come largely from the end of the period. The results of his calculations are shown in Figure 1. Since the Clark price index tracks many more items, it is less volatile. The real wage index surges and falls less sharply. Clark confirms the earlier, pessimistic results by Phelps-Brown and Hopkins for the period after 1500 - it wasn't until 1850 that the average Englishman had a real wage that was greater than his counterpart's in 1500.

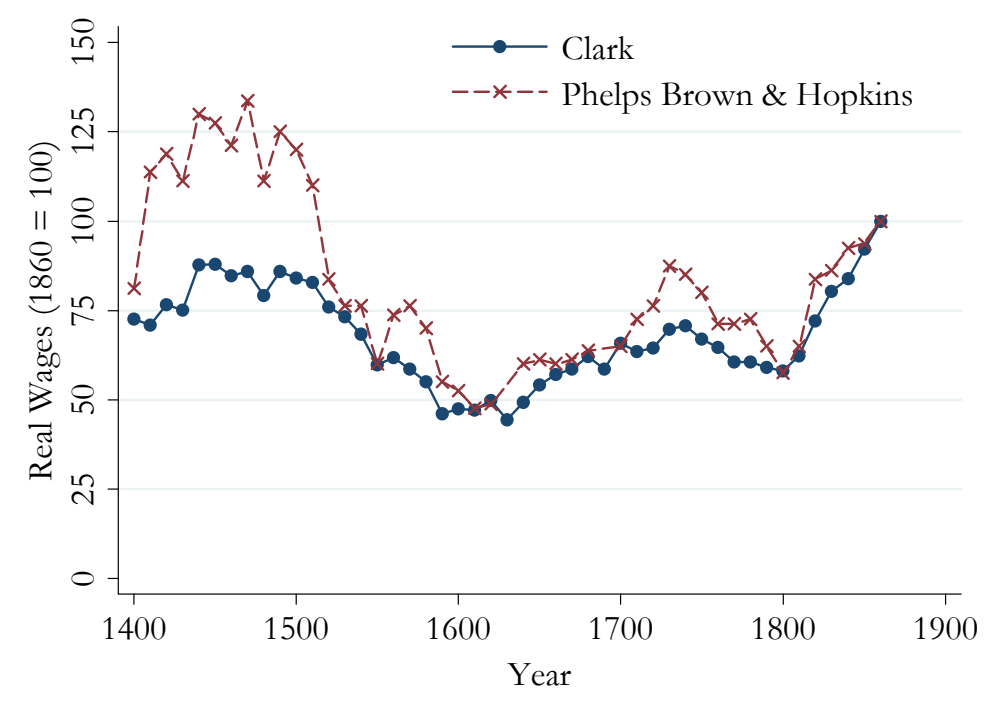

Figure 1: Real income in England, 1400-1850

The question if living standards improved after 1750 - the classic period of the industrial revolution - has been hotly debated since the days of Marx and Engels. For period 1770-1850, Clark (2005) finds larger increases than earlier authors had suggested. Initially, estimates by Lindert and Williamson $(1983,1985)$ implied large wage gains. Their cost-of-living indices were comprehensively revised by Feinstein (1998), who expanded the range of commodities covered. By doing so, he found markedly smaller wage gains - a plus of 30\% between 1780 and 1850, instead of 
Lindert and Williamson's gain of close to 90\%. Recent analysis suggests a range of improvement between 40\% (Allen 2007) and 50\% (Clark 2005). ${ }^{15}$

None of the existing indices of living standards during the early modern period incorporate the value of new goods. Loschky (1980) changed the weight for manufactured goods by using a different definition of the consumption basked. Apart from this, the radical transformation of consumption patterns and diets between 1500 and 1850 has left little trace in economists' analysis of trends in the standard of living. We turn to these changing patterns next.

\section{The adoption of colonial goods after 1492}

Tea and coffee were new to Europe in the early modern period, while sugar had only been available in very limited quantities before 1500 . We summarize how each was first brought to Europe, how it was consumed, and the corresponding changes overseas.

Sugar can be derived from a variety of sources-sugarcane, sugar beets, sorghum, honey, and other products. Early forms of sugar were available in small quantities at prohibitive prices. From the twelfth century onwards, medieval court records show that English kings consumed sugar. ${ }^{16}$ Europe's first taste of sugar derived from sugar cane came courtesy of Arab conquerors. Sugarcane production had reached Valencia and Sicily by the 10th century (Mintz 1985). The Crusaders are said to have encountered Egyptian sugar when they advanced into Syria. From there, cultivation of sugarcane spread to Cyprus. It was also grown in the Azores, the Canary Islands and on Madeira before reaching Brazil in the 1520s (Braudel 1988).

By 1572, a French observer commented that "people devour it out of gluttony... What used to be a medicine is nowadays eaten as a food.”17

The introduction of sugar to the New World facilitated large increases in output. Sugar refining became technically more sophisticated, producing a whiter, more consistent product. As Europe's taste for sugar developed, 'sugar barons' in the Caribbean and elsewhere became rich. Using imported slave labor, sugar cane was eventually cultivated in most European colonies with a suitable climate. Rum was

\footnotetext{
${ }^{15}$ Clark's (2005) index, based on additional data and a rebalanced consumption basket, suggests that living standards increased by more than allowed for by Williamson -- a rise by $50 \%$. Allen's latest reworking of the wage and price information again yields a more pessimistic view -- a plus of $40 \%$. ${ }^{16}$ It is mentioned in the pipe rolls of Henry II (1154-89). Cf. Mintz (1985).

${ }^{17}$ Cit. acc. to Braudel (1988).
} 
produced as a by-product. While medieval Cyprus produced no more than an estimated 50-100 tons of sugar per year, Santo Domingo in the 18th century alone produced 3,500 tons. England in 1700 imported approximately 10,000 tons; a century later, this figure had risen to 150,000 tons, according to some estimates (Braudel 1988).

As the price of sugar declined, consumption spread to the lower classes. It was frequently used as a substitute for a protein source, consumed in the absence of meat when and where meat was too expensive. Though the simple carbohydrates from sugar do not have all the nutritional qualities of a protein source, its consumption offered calories at a time where energy availability may have severely constrained labor input (Fogel 1994). In addition, sugar was used to add sweetness and calories to food and drink, especially to tea or coffee, or added in liquid or powdered form to a whole range of foods. ${ }^{18}$ It further had decorative value, as an ornament for other foods or in large-scale models of everything from houses and castles to human figures. ${ }^{19}$ Sugar was also used in medicines. Combining caffeinated drinks with sugar was a European innovation, as was the adding of milk (Goodman 1995). Sweetened tea became popular amongst all classes in England. Tea and sugar (or coffee and sugar) were therefore complementary goods. For the poor, a cup of sugary tea could reduce feelings of hunger, and give energy for a short time. Tea could serve as a substitute for a hot meal, especially where heating fuel was in scarce supply (Mintz 1985).

Tea reached Europe from China in $1606 .^{20}$ By the 1630 s, it had spread to France; by the 1650s, to England via Holland. The English diarist and naval administrator Samuel Pepys describes trying it for the first time in $1660 .^{21}$ Establishing direct trade links with China was crucial for boosting the volume of imported tea. Until the East India Company imported tea from China, it was normally exported to Batavia first, from where it would be shipped in Dutch vessels. Tea consumed in England initially was shipped on Dutch vessels (Goodman 1995). However, by the middle of the $18^{\text {th }}$ century, the English had overtaken the Dutch as principal traders. Over the course of the $18^{\text {th }}$ century, English tea consumption increased by a factor of 400 - much of it smuggled from the continent to avoid high

\footnotetext{
${ }^{18}$ Sugar in liquid form is called treacle, a byproduct that remains after the sugarcane is crushed, boiled and processed through a centrifuge. Being dark in color and retaining more impurities than white sugar, it was sold at a lower price and popular amongst the lower classes.

${ }^{19}$ Mintz (1985).

${ }^{20}$ Goodman (1995).
} 
customs duties. Outside the British Isles, tea was only consumed in substantial quantities in Holland, Russia, and parts of Northern Germany. Production in English colonies took some time to become quantitatively important. It was only after the 1850s that the East India Company began production on the subcontinent on any scale. No tea produced in India reached Britain before 1850 (Forrest 1973).

Coffee was probably consumed as early as AD 800-1000 in Yemen and Ethiopia. It spread throughout the Middle East, before reaching Europe via Venice by 1615. By the middle of the 17th century, coffeehouses were springing up in many larger European cities (Schivelbusch 1992). By the 18th century, Paris alone had 600700 cafés (Braudel 1988). Initially, most coffee reached Europe via the Mediterranean, having been grown in Yemen. Consumption surged after European powers took control of cultivation and distribution. The Dutch plantations in Java and Surinam started production shortly after 1700. In a few years, they had replaced all imports from the Arabian Peninsula. France began production on Martinique and Saint Domingue, and half a century later, England did the same on Jamaica. Production increases were swift. By 1789, Saint Domingue produced 40m pounds. Braudel (1988) estimates that some fifty years earlier, total European consumption reached $4 \mathrm{~m}$ pounds.

Europeans first encountered tobacco during the voyages of discovery. Columbus noted the smoking of tobacco by Native Americans on Cuba in November 1492. Afterwards, it took almost a century for consumption to grow significantly. The plant was largely treated as a botanical curiosity. It was only in the 1570s that the medical writings of Nicolas Monardes, who wrote a compendium on the plants of the New World, gave a push to tobacco use. Europeans used it as snuff, as chewing tobacco, and in pipes. The use of cigarettes first became common in Spain, and then spread to other countries. Initially produced by Native Americans, Spanish settlers in the New World eventually learned to produce it themselves. It was cultivated in Spain from the 1550s, and then spread to Italy, the Balkans, Java, the Philippines, and India. However, production in the North American colony of Virginia overtook all other sources of tobacco. By 1700, almost all European imports came from either Virginia or Brazil. England imported it on a vast scale, only to re-export it to the continent. By the early $18^{\text {th }}$ century, Virginia tobacco exports alone filled 200 boatloads per year

\footnotetext{
${ }^{21}$ Entry for 25 September 1660, cit acc. to Pepys (1854).
} 
(Braudel 1988). Mokyr (1988) estimates that by the end of the 1790s, the English consumed an average of 1.12 lbs of tobacco per capita.

The spread of hot, caffeinated drinks transformed eating habits. Over the course of the early modern period, breakfast was changed completely. It went from a relatively heavy meal, often consisting of porridge or other grains, with some cold cuts, combined with wine or beer, to the modern-style, often light meal. Tea and coffee, more likely than not sugared, were combined with bread or pastry. As an English observer in 1722 noted: "before the use of tea, breakfasts were more substantial; milk in various shapes, ale and beer, with roast cold meat... sack and wines for the higher orders of mankind". ${ }^{23}$ Something similar occurred in France. A Parisian observer noted the change in consumption amongst all classes:

Consumption has tripled in France; there is no bourgeois household where you are not offered coffee, no shopkeeper, no cook, no chambermaid who does not breakfast on coffee with milk in the morning. In public markets and in certain streets and alleys in the capital, women have set themselves up selling what they call café au lait to the populace. ${ }^{24}$

By the middle of the $19^{\text {th }}$ century, Friedrich Engels (1844) commented in his The Condition of the Working Class in England emphasized the importance of tea for all groups:

The better paid workers ... have good food as long as this state of things lasts; meat daily, and bacon and cheese for supper. Where wages are less, meat is used only two or three times a week, and the proportion of bread and potatoes increases. Descending gradually, we find the animal food reduced to a small piece of bacon cut up with the potatoes..., until on the lowest round of the ladder, among the Irish, potatoes form the sole food. As an accompaniment, weak tea, with perhaps a little sugar, milk, or spirits, is universally drunk. Tea is regarded in England, and even in Ireland, as quite as indispensable as coffee in Germany, and where no tea is used, the bitterest poverty reigns.

Even at the very bottom of the social hierarchy, according to Engels, tea and sugar were consumed regularly.

By the end of the 18th century, what had once been luxury goods, enjoyed by the few, was being consumed en masse. In 1800, the European continent as a whole imported $120 \mathrm{~m}$. pounds of coffee, $125 \mathrm{~m}$. pounds of tobacco, $40 \mathrm{~m}$. pounds of tea, and $13 \mathrm{~m}$. pounds of chocolate (Braudel 1988). Table 1 shows take-up of new colonial goods in a number of countries. In combination, the introduction of coffee, tea, and sugar transformed European consumption habits. Production sites had been established around the globe, mostly in European colonies. A vast trade of slaves

\footnotetext{
${ }^{23}$ Cit. acc. to Goodman (1995).

${ }^{24}$ Braudel (1988).
} 
provided the labor force necessary to satisfy European appetites, producing the kegs of molasses, sacks of coffee and bales of tobacco that sailed to the old continent in thousands of ships. The reliability of the supply system was remarkable. One historian argued that, by the late $18^{\text {th }}$ century, European "consumers could often rely on the availability of sugar, tea, or tobacco more certainly than on the supply of dairy products and some cereals.” (Shamas 1990).

Consumers clearly had a strong preference for new overseas products, as their rapid adoption by all classes shows. What has been missing is a good way to assess the impact on living standards.

Table 1: Consumption of colonial luxuries in Europe, early modern period (lbs per head and year)

\begin{tabular}{|c|c|c|c|c|c|c|}
\hline & \multicolumn{2}{|c|}{ Sugar } & \multicolumn{2}{|c|}{ Coffee } & \multicolumn{2}{|c|}{ Tea } \\
\hline \multirow{4}{*}{ England } & $1670 \mathrm{~s}$ & 2.2 & $1699-1701$ & 0.1 & 1722 & 0.6 \\
\hline & 1700-9 & 5.7 & $1749-51$ & 0.1 & $1750-9$ & 1.1 \\
\hline & $1750-9$ & 11.0 & 1801 & 0.1 & $1804-6$ & 1.7 \\
\hline & $1770-9$ & 23.1 & 1841 & 0.5 & 1844-6 & 1.8 \\
\hline \multirow{3}{*}{ Belgium } & 1800 & 3.6 & 1790 & 0.1 & $1720-9$ & 0.1 \\
\hline & $1850-4$ & 6.6 & $1850-4$ & 8.8 & $1850-4$ & 0.02 \\
\hline & $1730-4$ & 1.0 & $1781-9$ & 0.5 & & \\
\hline \multicolumn{7}{|l|}{ France } \\
\hline & $1788-90$ & 2.1 & $1815-24$ & 0.5 & $1825-34$ & 0.1 \\
\hline & 1830 & 4.4 & $1825-35$ & 0.6 & $1835-44$ & 0.1 \\
\hline \multirow{3}{*}{ Austria } & 1780 & 0.3 & 1780 & 0.1 & & \\
\hline & 1800 & 0.9 & 1800 & 0.1 & & \\
\hline & 1830 & 2.2 & & & & \\
\hline
\end{tabular}

Source: adapted from DeVries (2008)

\section{Smuggling}

Data on consumption of new goods in Britain comes from official import statistics. These will underestimate true consumption if goods arrive via an illegal channel. At various times, smuggling was rife in Britain during the early modern period. Tariffs and excise taxes were high, especially for tea and tobacco. A standard way to smuggle goods into the country was to officially 're-export' colonial goods, and then land them 
illegally. ${ }^{25}$ There is general agreement that sugar and coffee were affected much less, not least because the weight/value ratio was less favorable. ${ }^{26}$ Tea and especially, tobacco, were easier to smuggle. Mokyr (1988) estimated that between half and over 90 percent of all tobacco consumed in Great Britain had been smuggled.

Standard statistics on retained imports deduct re-exports fully from the import figures, some of which may have returned as smuggled goods to Great Britain. Tariffs in general declined during our period. For example, duty on tea fell from a high of 125 percent of net cost in 1736-40 to a mere 12.5 percent in 1787-91 (Cole 1958). The incentive to smuggle therefore declined markedly over time (though by the 1820s, tea duty had returned to 100 percent of net cost); the share of smuggled goods in final consumption probably fell. ${ }^{27}$ Since we examine the value of new goods in the light of how quickly their consumption rises, the legal import figures may paint too optimistic a figure - real consumption may have risen much less during the periods of tariff reductions. The extent to which one can correct for smuggling in British import statistics is controversial (Cole 1958, Hoh-Cheung and Mui 1975, Cole 1975). In the main data section, we will use the 'official' statistics on retained imports. We will examine the issue of smuggling, and its impact on our results, in the robustness section.

\section{Data}

In calculating welfare gains for colonial luxuries, we use three types of data: consumption, price and income. For price data we rely on the recent work by Clark (2004) and Allen (1992) who have computed detailed price series for the period. Since his price series extend back to the medieval period, and tracks a larger number of products, we use Clark as the primary source. Allen's data serve as a robustness check for sugar and tea; he does not provide price data for coffee. Consumption data is from a combination of sources. A continuous series would be preferable, but is unfortunately not available. The consumption data we use comes from five sources: Mokyr (1988), Mitchell \& Deane (1962), Deerr (1950), Cole (1958), and Davis

\footnotetext{
${ }^{25}$ This required forging the landing documents from a foreign port, or bribing an official to provide them (Hoh-Cheung and Mui 1975).

${ }^{26}$ Mokyr (1988).

${ }^{27}$ In figure A1 in the appendix, we plot legal imports and the tariff rate side-by-side.
} 
(1979), all estimated using retained imports (imports minus re-exports) per capita.

Finally we use daily workers’ wages from Clark (2005) for income.

Figure 2 presents the Allen and Clark series for the real price of sugar on the left panel with sugar consumption in pounds per year on the right, from 1600 to 1850 . The real price of sugar, as for all of these series, is derived by taking the nominal price and dividing it by the CPI. The Clark series shows the price of sugar in real terms (plotted as circles) declining dramatically over a relatively short period. It falls in real terms from a high of over 32 pence per pound in 1600 to less than 15 by the 1650s, before declining to 5.7 pence per pound in 1850. The Allen series (x-marks), begins later, and shows a less dramatic price decline, starting at 10 pence in 1660 and ending at 6 by 1850 .

Sugar consumption is derived from retained imports: total imports into Britain minus re-exports. We obtained per capita consumption by dividing total retained imports by population. ${ }^{28}$ Our sugar consumption quantity data combines two series: Deerr (1950) for the years 1700-1789 and Mokyr (1988) for the years 1794-1796 to 1854-1856. Deerr estimates 4 lbs. of sugar consumed per capita in 1700, growing to 12 lbs. in 1780. From here Mokyr estimates retained imports of 16 lbs. per capita in 1794-96 growing to 33 lbs. in 1854-56. Retained imports for sugar are not available for the $17^{\text {th }}$ century. Historical descriptions (Deerr 1950) suggest that consumption increased slowly during the $17^{\text {th }}$ century. We set an initial point of zero consumption of sugar at $1600 .^{29}$

\footnotetext{
${ }^{28}$ Population figures are from appendix tables A5.2, A5.3 and A6.1 in Wrigley et al. (1997).

${ }^{29}$ Excluding interpolated points leaves our conclusions broadly unaffected.
} 

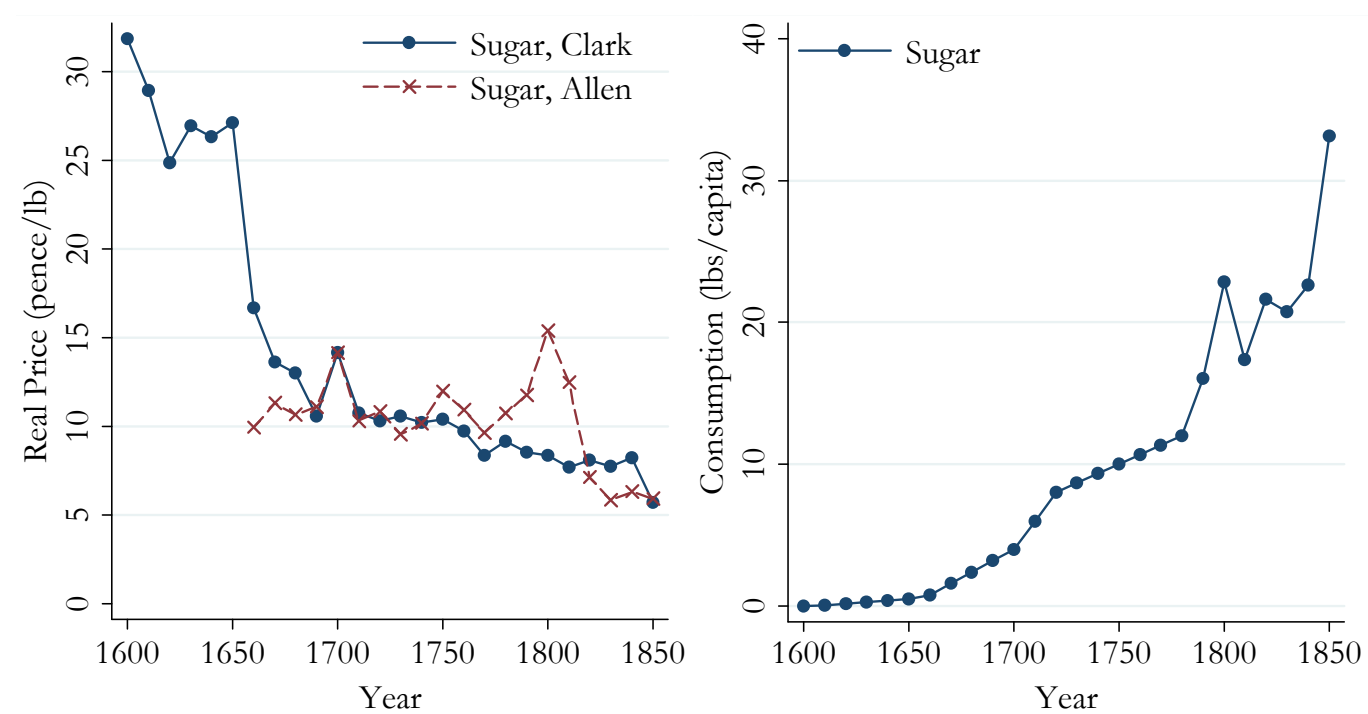

Figure 2: Real Sugar Prices and Sugar Consumption Per Capita in England, 1600-1850

Figure 3, shows the real price of tea (left panel) and consumption per capita (right panel). The price of tea, compared to sugar, shows an even more dramatic price decline. The Clark series falls from a high of 614 pence per pound in 1690 to 54 pence in 1850, a price decline of 91\%. The Allen price series begins in 1760 and shows a high degree of co-movement (correlation coefficient 0.89) with the Clark series. Our consumption series for tea is derived from three sources, Forrest (1973) for the years 1700 to 1770, Davis (1979) for 1784-86, and Mokyr for 1794-96 to 1854-56. Forrest calculates 0.01 lbs. per capita of tea consumption in 1700 growing to 0.74 in 1770. Davis estimates 1.36 lbs. for 1784-86, and Mokyr calculates 1.6 lbs. in 1794-96 growing to 2.43 for 1854-56. The combined consumption series show tea consumption increased rapidly over the period. We set a point of zero consumption for tea at the year 1690; qualitative historical accounts, such as the existence of tea houses starting in 1660s in London, (Forrest, 1973) suggest there is some consumption before that period. We can infer from retained imports beginning in 1700 that what was consumed remains very small in per capita terms, suggesting 1690 to be an appropriate starting point. 

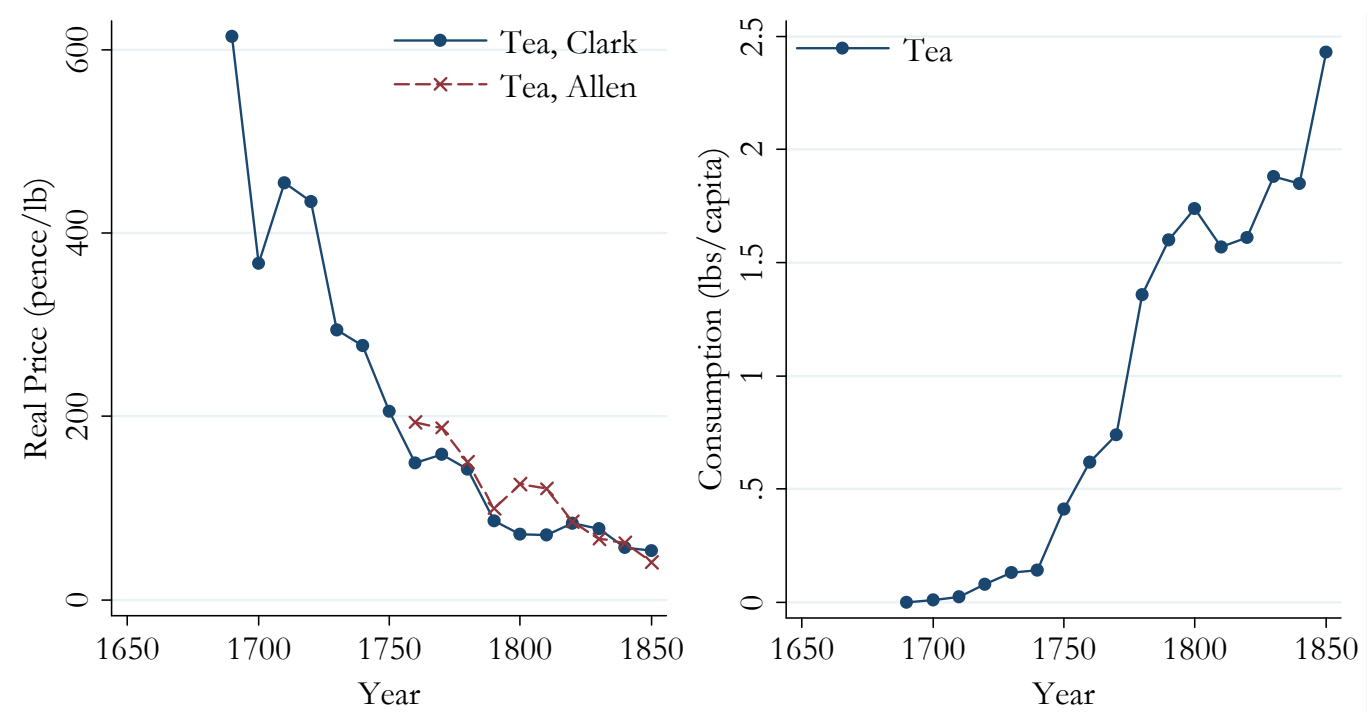

Figure 3: Real Tea Prices and Consumption Per Capita in England, 1600-1850

Finally, changes in the price of coffee (left panel) as well as quantities consumed (right panel) are shown in Figure 4. The price of coffee, only available for the Clark series, declined from a high of 137 pence per pound in 1710 to a low of 22 pence per pound in 1850 . This is a reduction of $84 \%$-- smaller than in the case of tea, and similar to the one for sugar. Per capita consumption comes from two sources: Mitchell and Deane (1962) for the years 1700 to 1770 and Mokyr (1988) for 1784-86 to 1854-56. Retained imports from Mitchell and Deane show small amounts of consumption, starting at $0.002 \mathrm{lbs}$. per capita in 1700 and growing to about $0.02 \mathrm{lbs}$. per capita in 1770 . Mokyr estimates 0.01 lbs. per capita of coffee consumed in 178486 growing to $1.59 \mathrm{lbs}$. per capita in 1844-56 and declining again to $1.39 \mathrm{lbs} /$ capita in $1854-56 .^{30}$

As a percentage of household spending, coffee was not as important as tea. By 1850, the English consumed a full pound of tea more than of coffee. This is partly because the price of coffee was 2.5 times higher than that of tea. Coffee briefly became fashionable for a period in the mid- $17^{\text {th }}$ century. However, its consumption across Britain never took hold until the $19^{\text {th }}$ century, and all indications suggest overall consumption remained low (Cowan 2005). We assume zero consumption of coffee in 1690, motivated by small aggregate consumption per capita in the years immediately after.

\footnotetext{
${ }^{30}$ Mokyr (1988) attributes the unstable consumption patterns of coffee to changing preferences.
} 

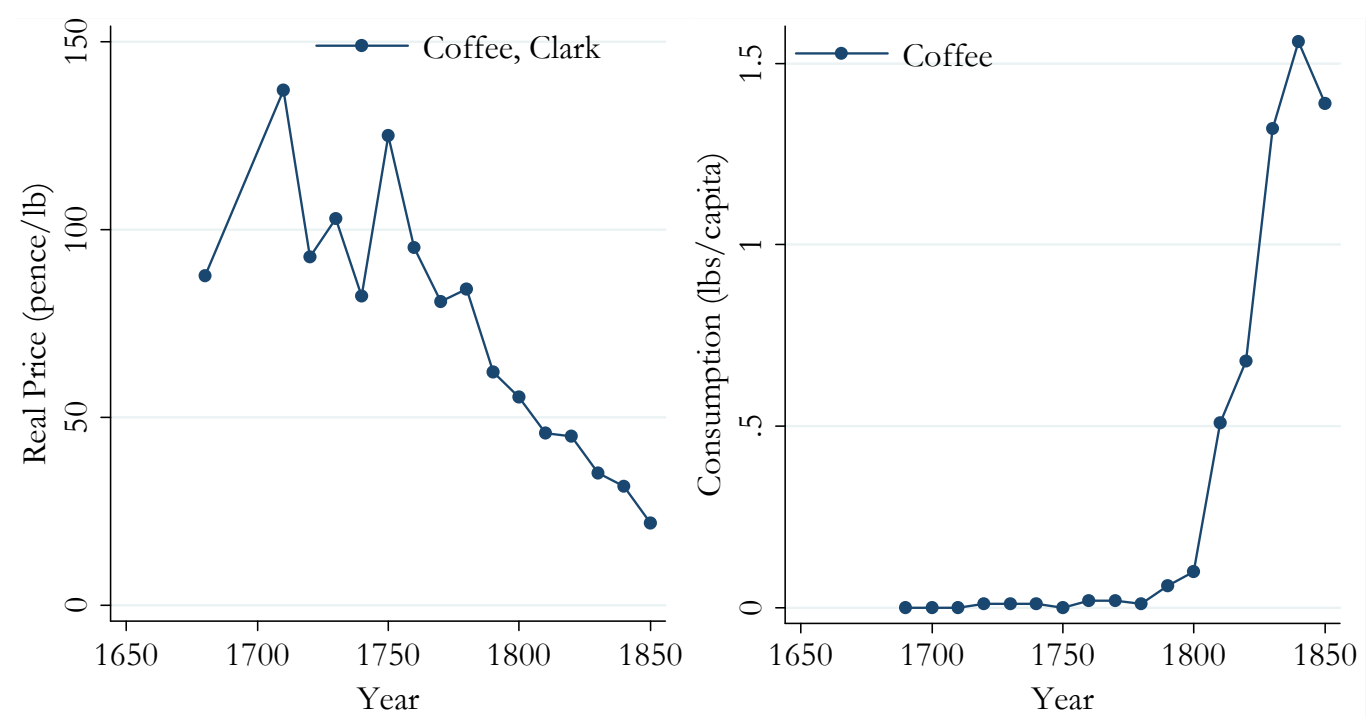

Figure 4: Real Coffee Price and Consumption Per Capita in England, 1600-1850

Income data comes from three series in Clark (2007). Clark provides daily wages for 'farm', 'craft', and 'building laborer' in pence per day. Table 2 below reports daily (nominal) wages for a subsection of our period and the budget shares of tea and sugar implied by the consumption per capita data discussed earlier. ${ }^{31}$

To translate Clark’s daily wages into annual per capita incomes we calculate days of work per year via implied budget shares for new goods. Since we know annual spending on them, and know daily wages and the budget share, we can simply solve for the number of days implied. This method suggests approximately 140 days of work per year. ${ }^{32}$ Feinstein (1998) shows sugar accounting for $4.8 \%$ of a household's budget in 1788-92 (column 5). Using consumption per capita of sugar from retained imports, our estimated incomes show sugar to be $4.89 \%$ of income in 1790, a very close match to Feinstein's estimate. For 1830 our estimated incomes show sugar accounts for 3.9\% of a household's budget (column 3), below the $4.6 \%$ estimated by Feinstein in 1828-32. (column 5). With regard to tea, in 1790 using our income estimates we calculate tea to occupy $4.9 \%$ of a household's budget share, slightly overestimating Horrell's estimate of $3 \%$ for $1787-96$. We estimate tea to be $2.8 \%$ of a household's budget in 1850, slightly above Horrell's estimate of $2.1 \%$ for

\footnotetext{
${ }^{31}$ Table A2 presents the full wage data.

${ }^{32}$ The number for adult males was probably much higher (Clark and van der Werf 1998, Voth 2001). Note that we are estimating the number of working days per Englishman, from infant to the elderly, in adult male wage equivalents.
} 
1840-54. Overall our per capita income estimates do not consistently overestimate or underestimate actual budget shares. ${ }^{33}$

Table 2: Wages and Budget Shares

\begin{tabular}{ccccccc}
\hline \hline & & \multicolumn{2}{c}{$\begin{array}{c}\text { Estimated Using } \\
\text { Daily Wages }\end{array}$} & & \multicolumn{2}{c}{$\begin{array}{c}\text { From Historial Records } \\
\text { of Budget Shares }\end{array}$} \\
\cline { 3 - 4 } \cline { 6 - 7 } Year & $\begin{array}{c}\text { Daily Wages } \\
\text { (pence) }\end{array}$ & $\begin{array}{c}\text { Sugar } \\
\text { (Budget \%) }\end{array}$ & $\begin{array}{c}\text { Tea } \\
(\text { Budget \%) }\end{array}$ & & $\begin{array}{c}\text { Sugar - Feinstein } \\
\text { (Budget \%) }\end{array}$ & $\begin{array}{c}\text { Tea - Horrell } \\
\text { (Budget \%) }\end{array}$ \\
\hline 1780 & 17.17 & $3.63 \%$ & $6.36 \%$ & & & \\
1790 & 18.41 & $4.89 \%$ & $4.93 \%$ & & $4.83 \%^{a}$ & \\
1800 & 23.01 & $7.33 \%$ & $4.80 \%$ & & & \\
1810 & 30.47 & $4.32 \%$ & $3.58 \%$ & & & \\
1820 & 30.60 & $4.63 \%$ & $3.57 \%$ & & & \\
1830 & 30.14 & $3.90 \%$ & $3.55 \%$ & & $4.55 \%^{b}$ & \\
1840 & 30.79 & $4.30 \%$ & $2.42 \%$ & & & $2.13 \%^{d}$ \\
1850 & 31.29 & $4.07 \%$ & $2.82 \%$ & & & \\
\hline
\end{tabular}

Notes: Sources discussed in text. Daily wages are in nominal terms. Some individual years of data have been adjusted to closest matching decade: ${ }^{a} 1788-92 .{ }^{b} 1828-32 .{ }^{c} 1787-96 .{ }^{d} 1840-54$

Consumption of colonial luxuries rose with incomes (Horrell 1996, Vanderlint 1734). However, heterogeneity should not be exaggerated. Mokyr (1988) found that colonial goods had positive income elasticities that decreased with income; consumption per capita reached a saturation level, which Mokyr estimates to be between 2 to 3 times the average level of consumption in 1855. Because of this, we can be fairly certain that welfare gains did not just accrue to a few upper-class families consuming the new goods. The qualitative historical literature emphasizes how the consumption of tea and sugar spread throughout most social classes. The only exception to this is the earliest part of the period, when consumption was limited to the wealthy.

\footnotetext{
${ }^{33}$ Aggregate consumption of these new goods implied through our data corroborates with total value of sugar and tea consumed in 1801 from Appendix 2 in Horrell (1996).
} 


\section{Method and Results}

How should we value the spread of new, hot, caffeinated drinks and other new goods from the New World? In this section, we briefly summarize the methodology developed by Greenwood and Kopecky (2009), which we then apply to tea, coffee, and sugar. We also examine the sensitivity of our results.

\section{Method}

Consumers purchase two types of products: new and old. $U(c)$ describes the utility they derive from the latter; $\mathrm{V}(\mathrm{n})$ the one from the former. The parameter $\theta$ is the share of expenditure on the new good. Consumers maximize

$W(y, p)=\max _{c, n}[\theta U(c)+(1-\theta) V(n)]$, with $0<\theta<1 ; c, n \geq 0$; and subject to $c+p n=y$

where c is consumption of the "old good", $\mathrm{n}$ is consumption of the "new good", $\mathrm{c}$ serves as a numeraire, $\mathrm{p}$ is the relative price of new goods, and $\mathrm{y}$ is income. Both the consumption of new and old goods follow standard CRRA preferences, with one important qualification in the case of new goods:

$U(c)=\frac{c^{1-\rho}}{1-\rho}$, with $\rho \geq 0$

and

$V(n)=\frac{(n+v)^{1-\rho}}{1-\rho}$, with $V(n)=\frac{v^{1-\rho}}{1-\rho}>-\infty$ and $V_{1}(0)=v^{-\rho}$

The modifications of standard CRRA preferences ensure that the marginal utility of the first item of a new good is not infinitely large. Effectively, the last two conditions ensure that at zero consumption of the new good, marginal utility is $v^{-\rho}$. This is achieved by shifting the standard utility function by the parameter $v^{34}$

This leads to a threshold price, $\hat{p}$ for the new good where $\hat{p} \geq \hat{P}(y)$ and $\hat{P}(y)=\frac{1-\theta}{\theta} v^{-\rho} y^{\rho}$. If the price of the new good is higher that this threshold price, consumption of the new good will be zero. Greenwood and Kopecky show that below the threshold price consumption of the new good is given by 
$\hat{n}=\frac{y+p v}{p+[(1-\theta) / \theta]^{-1 / \rho} p^{1 / \rho}}-v$

Welfare changes are calculated from the indirect utility functions with and without access to the new good. Greenwood and Kopecky (2009) define two measures of the welfare gain from new goods - equivalent variation (EV) and compensating variation (CV). Suppose there are two states of the world: In state 2, consumers have access to the good; in state 1, they do not. State 1 can be considered as a special case of state 2 where the price of the new good is infinite. The equivalent variation is the increase in income needed to give the consumer in state 1 (without access to the new good) the same level of utility as a consumer in state 2 (with access). This can be written as

$W\left(\left(1+\lambda_{E V}\right) y_{2}, \infty\right)=W\left(y_{2}, p_{2}\right)$

where $W\left(y_{t}, p_{t}\right)$ is the indirect utility function which has as inputs current prices $p_{t}$ and income, $y_{t}$. EV is expressed in percent of income in state 2 .

Compensating variation is defined as the amount of income a consumer would be willing to lose, provided he kept access to the new good. We can think of this as the amount of income a consumer would be willing to forego in state 2 in order to maintain access to the price $p_{2}$ as opposed to facing an infinite new good price. We can formally describe this as

$W\left(\left(1-\lambda_{C V}\right) y_{2}, p_{2}\right)=W\left(y_{2}, \infty\right)$

$\mathrm{CV}$ is similarly expressed as a percentage of income in state 2 . With quasi-linear preferences, the results for both will be identical. We next calculate how much consumers would have been willing to forego of their income in 1850 to keep access to tea, sugar, and coffee.

\footnotetext{
${ }^{34}$ As Greenwood and Kopecky (2009) note, the indirect utility function can very well have a solution with $n=0$, since the marginal utility from old goods at low consumption levels can near infinity (due to habit formation), whereas that for new goods is possibly lower.

${ }^{36}$ In one of our robustness tests, we also use an alternative estimator that uses absolute deviations. Results are broadly unaffected.
} 


\section{Main results}

The welfare measures for the introduction of new goods from overseas can be calculated by using observed data on income (y) prices (p) and new good consumption (n) to calibrate the preference parameters. The preference parameters are the coefficient of relative risk aversion $(\rho)$, the weight on utility of non-new good consumption $(\theta)$, and the utility shift parameter $(v)$ that corresponds to the marginal utility of zero new good consumption, given by $v^{-\rho}$. To calculate these preference parameters, we follow Greenwood and Kopecky, and use a two-step procedure. The utility functions predict a mapping of income and price of old and new goods to quantities consumed, for any set of values for $p, y, v, \theta$, and $\rho$. Using equation (1) to calculate $\hat{n}$, we calibrate $\nu, \theta$, and $\rho$ to minimize the sum of squares of differences between observed new goods, $n$, and the predicted new goods, $\hat{n} \cdot{ }^{36}$ As in Greenwood and Kopecky, we constrain consumption in the beginning of the period to zero. Due to the nonconvex nature of the equation (1), a Nelder-Mead nonlinear optimization algorithm is used for the sum of squares minimization.

Greenwood and Kopecky obtain parameter values of $\rho=0.993, \theta=0.994$, and $v=6 \times 10^{-4}$. We deviate from the calibration procedure used by G\&K and use a composite index of sugar, tea, and coffee to estimate the value for $\rho$ that best predicts new good consumption jointly. The reason is that we think of $\rho$ as an underlying parameter that should govern the adoption of all colonial goods. With CRRA preferences, $\rho$ measures risk aversion, and $1 / \rho$ the intertemporal elasticity of substitution. There is little reason to assume that consumers should have different rates of time preference in the context of different overseas luxuries. We therefore estimate $\rho$ with data for all the goods for which we have information. This yields an estimate of $\rho$ of 0.9395 .

Using the jointly-calibrated value for $\rho$, we estimate the remaining preference parameters and their resulting welfare estimates for the new goods separately. The results are shown in panel A of Table 2. The welfare estimates are large. The results for both sugar and tea each show an equivalent variation of more than $7 \%$. Had they disappeared in 1850, consumers would have had to receive an extra $15.9 \%$ in income to make up for the loss. The compensating variation is also large, and of a very similar magnitude $-14.9 \%$. This is how much 1850 s consumers would have been willing to have their incomes cut to retain access to tea and sugar. To this, we also 
have to add the gains from coffee, which brings the total to $17.33 \%$ for $\mathrm{EV}$, and $16.4 \%$ for CV. This suggests that the introduction of these three 'small luxuries' had big consequences for the well-being of the English population. ${ }^{37}$

If we replicate the Kopecky-Greenwood approach exactly and estimate $\rho$ separately for each new good, we obtain broadly similar results. The parameter values and estimates of EV and CV for our set of goods shown in panel B of table 2. We constrain $\rho$ to lie in the interval $(0,2]$. The estimation procedure finds minima for the function at $\rho=0.72$ for sugar, 1.49 for tea, and 2 for coffee. Compared to the results in panel A, we see that $\rho$ from joint estimation produces marginally lower $R^{2}$ values for each good. The CV and EV for tea and coffee rise, while the ones for sugar decline. The total welfare gains are now even larger (20-23\%).

Table 3: Welfare gains from sugar, tea, and coffee, England (1600-1850)

\begin{tabular}{ccccccccc}
\hline \hline New Good & Year Range & $E V$ & $C V$ & $\nu$ & $\rho$ & $\theta$ & $R^{2}$ \\
\hline Panel A. Results with $\rho$ calibrated at & $\mathbf{0 . 9 3 9 5}$ & & & & \\
Sugar & $1600-1850$ & $8.0 \%$ & $7.6 \%$ & 0.0993 & 0.9395 & 0.9435 & 0.8517 \\
Tea & $1690-1850$ & $7.9 \%$ & $7.3 \%$ & 0.0572 & 0.9395 & 0.9590 & 0.7718 \\
Coffee & $1690-1850$ & $1.5 \%$ & $1.5 \%$ & 0.1255 & 0.9395 & 0.9875 & 0.8508 \\
\cline { 3 - 5 } & & $17.3 \%$ & $16.4 \%$ & & & & \\
Welfare Gain & & & & & & & \\
Panel B. Results with & $0<\rho \leq 2$ & & & & & \\
Sugar & $1600-1850$ & $6.4 \%$ & $6.2 \%$ & 0.0590 & 0.7216 & 0.9268 & 0.8596 \\
Tea & $1690-1850$ & $13.6 \%$ & $11.3 \%$ & 0.1550 & 1.4894 & 0.9711 & 0.8066 \\
Coffee & $1690-1850$ & $2.9 \%$ & $3.0 \%$ & 0.3857 & 2 & 0.9991 & 0.8871 \\
\cline { 3 - 4 } Welfare Gain & & $22.9 \%$ & $20.40 \%$ & & & & \\
\hline
\end{tabular}

Notes: The parameter values of $\nu, \rho$, and $\theta$ are calibrated by choosing values that minimize sum of squared error between predicted and actual new good consumption. In panel A, $\rho$ is fixed at 0.9395 and only $\nu$ and $\theta$ are chosen. EV refers to equivalent variation and CV to compensating variation. The parameter $\theta$ is the weight on utility from new good consumption, $\frac{1}{\rho}$ is the intertemporal elasticity of substitution, and $\nu$ is the new good utility shift.

With logarithmic preferences, (1- $\theta)$ should converge to the budget share for novel goods. The sum of $1-\theta$ for panel A of table 2 is $11 \%$. This is similar to the historical data. Sugar, tea, and coffee accounted for approximately $10 \%$ of food expenditure of working class households in 1790s England (Feinstein 1998), or 7\% of total expenditure. Given that consumption of these goods was greater amongst middle and

\footnotetext{
${ }^{37}$ It may be argued that at such low levels of income no expenditure is small.
} 
upper class households (not included in the Feinstein estimate), the results for $\theta$ seem to be in line with historical evidence. The values for $v$ also appear reasonable, perhaps even conservative, as the utility derived from the new goods is strictly decreasing in $v$. Since $v^{-\rho}$ gives the marginal value of the first quantity of a new good, our estimates imply a marginal value of 8.8 for sugar, 14.7 for tea, and 7.03 for coffee. This compares with a marginal value of 1582 for computers according to Greenwood and Kopecky. The $R^{2}$ for these goods varies between 0.77 and 0.85 , a lower degree of fit with the restriction on $\rho$, but still high considering the likely noise in the historical data.

Figures 5-7 illustrate the goodness of fit achieved by the estimation procedure. We plot predicted and actual expenditure on new goods for the specification in panel A of table 2. The predicted expenditures from equation (1), using the calibrated parameter estimates, do a good job in tracking actual values. In all cases, the predicted series is neither consistently above nor below the actual consumption path. As one would expect with historical data spanning centuries, the fit of our calibration exercise is not as high as with modern data; the $\mathrm{R}^{2}$ values for these graphs are 0.85 for coffee, 0.77 for tea and 0.85 for sugar. This compares with a value of 0.999 in the Greenwood-Kopecky study.

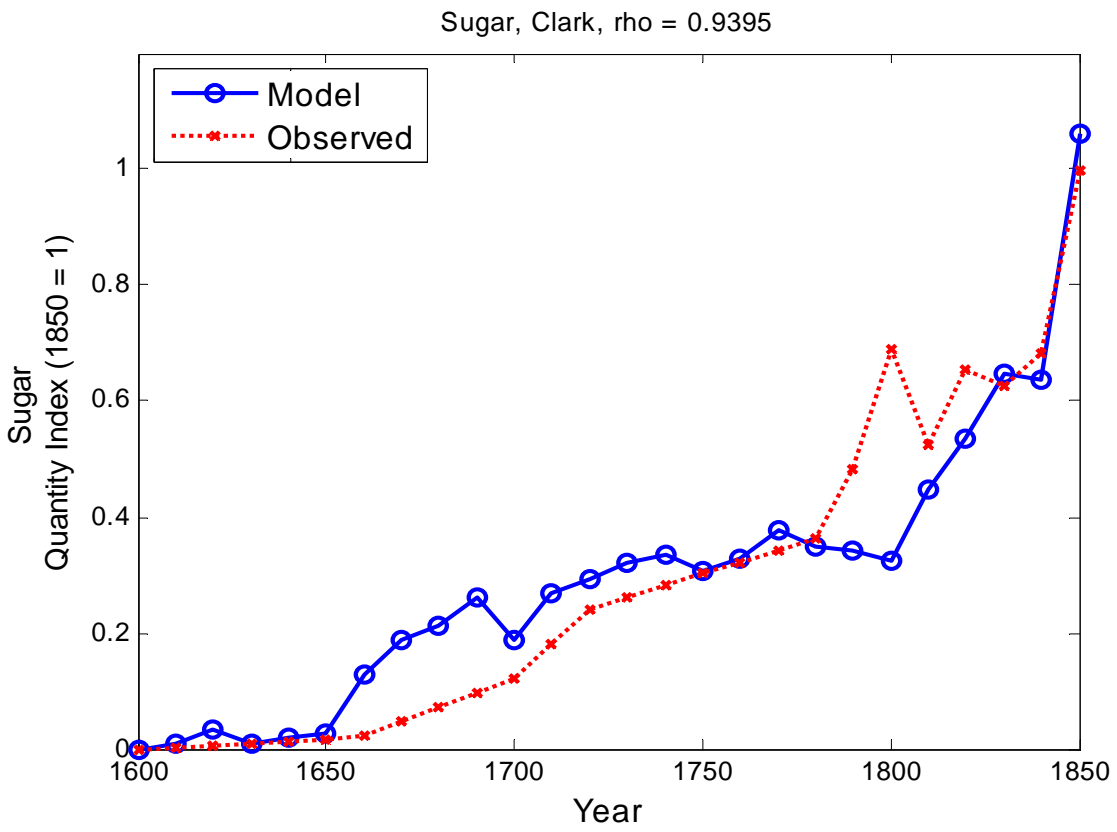

Figure 5: Predicted vs actual values for sugar consumption in England, 1600-1850 
Tea, Clark, rho $=0.9395$

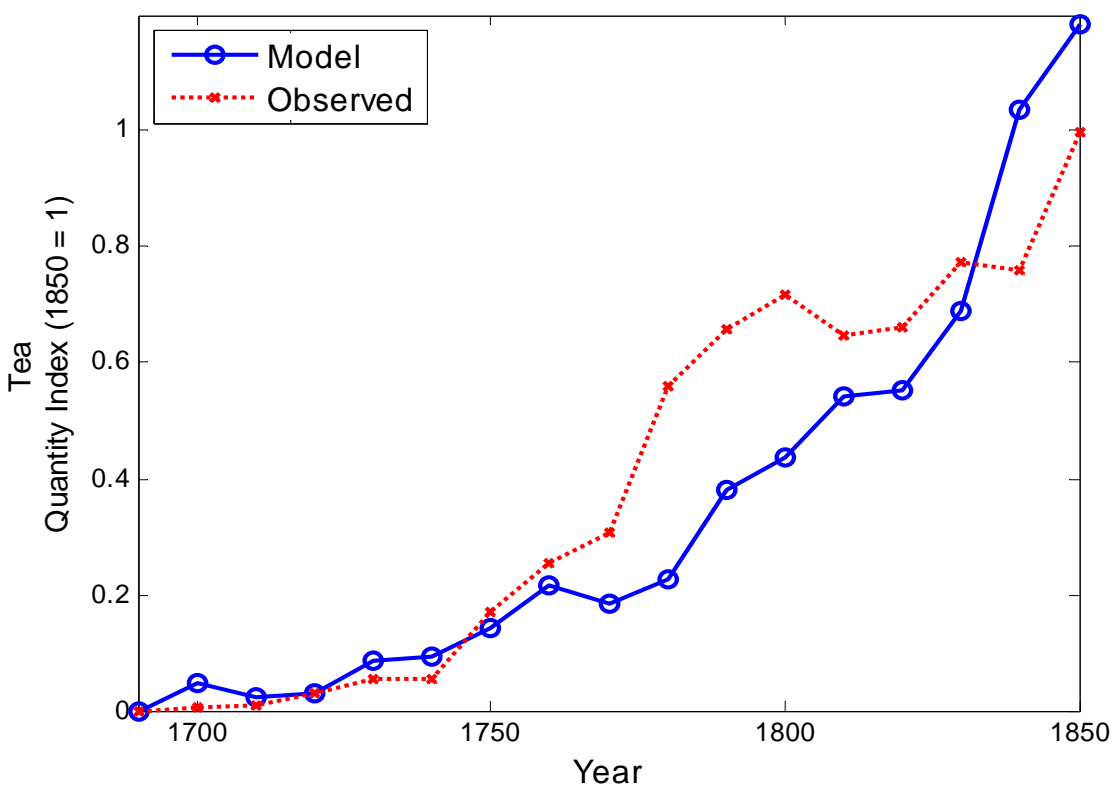

Figure 6: Predicted vs actual values for tea consumption in England, 1690-1850

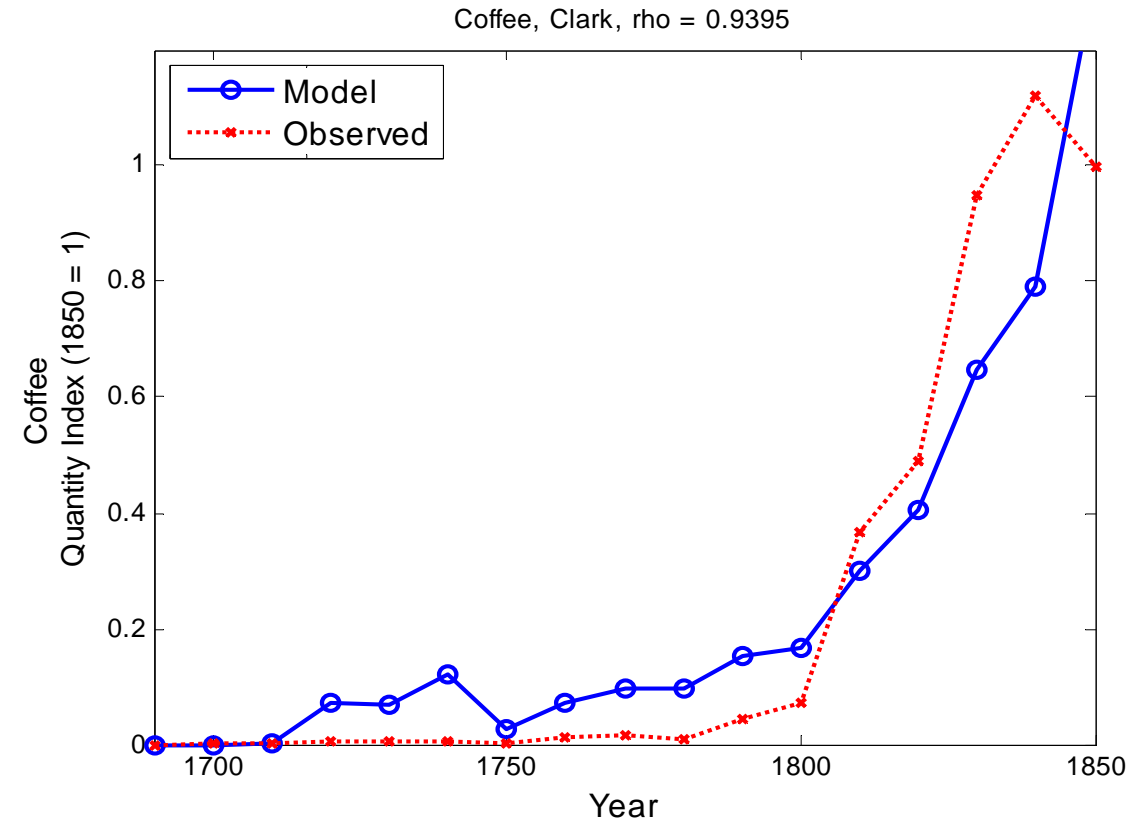

Figure 7: Predicted vs actual values for coffee consumption in England, 1690-1850

Our baseline results, summarized in table 2, suggest that colonial luxuries made consumers better off by a little more than one-sixth of final-period consumption. Far from a side-show in the history of living standards, the introduction of caffeinated hot beverages and sugar contributed substantially to the welfare of the first industrialized 
country. Before we conclude that that the history of living standards needs to be modified in the light of these findings, we examine the robustness of our result.

\section{Robustness}

We first examine the robustness of our findings to changing our implementation of the Kopecky-Greenwood method. We then use alternative data series, and examine the potential impact of smuggling on our estimates. Finally, we use a different method altogether, introduced by Hausman, to obtain estimates of the welfare gain from new goods. All alternatives suggest that our main result is plausible, perhaps even conservative - tea, sugar, coffee and tobacco raised European welfare substantially.

\section{Alternative parameter values}

Table 4 uses alternative values for $\rho$ and $v$. Since in a CRRA utility function, $\rho$ is also the degree of risk aversion, it may be instructive to experiment with higher values similar to those used in the finance literature. Panel A of table 3 examines this scenario. If we use $\rho=2$, we obtain values for the equivalent compensation of about $20 \%$ each for sugar and tea, and close to $3 \%$ for coffee. We find these values too high to be plausible. The overall budget shares implied by this approach also seem too low in this specification, and the implied values for $v$ are large.

If we use a lower value for $\rho$ than in our benchmark estimate ( $\rho=0.7$, shown in panel B), we find smaller values, but not markedly so. The sum of welfare gains from new hot beverages and sugar is $12.9 \%$, compared to the $17.3 \%$ when we used $\rho=0.9395$ in the baseline specification. Finally, since $v$ in our calibration/estimation exercise is on the high side, we constrain it to a value of 0.01 . While giving sensible results for coffee and sugar, this raises the welfare gain of tea to an implausible 22$30 \%$. Moreover, setting $v$ to 0.01 would also imply that we violate the restriction of zero consumption in the initial period. Overall, we conclude that our results are robust to alternative parameter values: Modifications tend to raise estimated welfare gains. 
Table 4: Robustness - alternative parameter values

\begin{tabular}{|c|c|c|c|c|c|c|c|}
\hline New Good & Year Range & $E V$ & $C V$ & $\nu$ & $\rho$ & $\theta$ & $R^{2}$ \\
\hline \multicolumn{8}{|c|}{ Panel A. Robustness of results using $\rho=2$} \\
\hline Sugar & $1600-1850$ & $20.3 \%$ & $14.4 \%$ & 0.2792 & 2 & 0.9806 & 0.8045 \\
\hline Tea & $1690-1850$ & $20.9 \%$ & $14.5 \%$ & 0.2494 & 2 & 0.9774 & 0.7963 \\
\hline Coffee & $1690-1850$ & $2.9 \%$ & $3.0 \%$ & 0.3857 & 2 & 0.9991 & 0.8871 \\
\hline Welfare Gain & & $44.1 \%$ & $31.9 \%$ & & & & \\
\hline \multicolumn{8}{|c|}{ Panel B. Robustness of results using $\rho=0.7$} \\
\hline Sugar & $1600-1850$ & $6.2 \%$ & $6.0 \%$ & 0.0551 & 0.7 & 0.9248 & 0.8595 \\
\hline Tea & $1690-1850$ & $5.5 \%$ & $5.3 \%$ & 0.0237 & 0.7 & 0.9510 & 0.6990 \\
\hline Coffee & $1690-1850$ & $1.1 \%$ & $1.2 \%$ & 0.0646 & 0.7 & 0.9763 & 0.8057 \\
\hline Welfare Gain & & $12.9 \%$ & $12.5 \%$ & & & & \\
\hline \multicolumn{8}{|c|}{ Panel C. Robustness of results using $\nu=0.01$} \\
\hline Sugar & $1600-1850$ & $6.8 \%$ & $6.4 \%$ & 0.0100 & 0.6199 & 0.9199 & 0.8531 \\
\hline Tea & $1690-1850$ & $30.8 \%$ & $21.7 \%$ & 0.0100 & 1.2126 & 0.9707 & 0.8209 \\
\hline Coffee & $1690-1850$ & $2.0 \%$ & $1.9 \%$ & 0.0100 & 0.7880 & 0.9828 & 0.8054 \\
\hline Welfare Gain & & $39.6 \%$ & $30.00 \%$ & & & & \\
\hline
\end{tabular}

Notes: $\mathrm{EV}$ refers to equivalent variation and $\mathrm{CV}$ to compensating variation. The parameter $\theta$ is the weight on utility from new good consumption, $\frac{1}{\rho}$ is the intertemporal elasticity of substitution, and $\nu$ is the new good utility shift.

\section{Alternative functional form}

The standard Greenwood-Kopecky specification assumes full separability between new and old goods in the utility function. This assumption may be too restrictive, especially since colonial goods were often combined with old goods when consumed. To relax this assumption, they experiment with a CES specification that allows them to measure the implied elasticity of substitution between new and old. Consumers then maximize

$U(c, n)=\left[\theta c^{\frac{\sigma-1}{\sigma}}+(1-\theta)(n+v)^{\frac{\sigma-1}{\sigma}}\right]^{1 /\left(\frac{\sigma-1}{\sigma}\right)}$

where $\sigma$ is the elasticity of substitution between new and old goods. They find an elasticity close to unity for the case of computer purchases. We repeat their exercise as an additional robustness check. Table 5 gives the results. 
Table 5: Robustness - alternative functional form

\begin{tabular}{lccccccc}
\hline \hline \multirow{2}{*}{ New Good } & Year Range & $E V$ & $C V$ & $\nu$ & $\sigma$ & $\theta$ & $R^{2}$ \\
\hline \multirow{2}{*}{ Sugar } & $1600-1850$ & $6.4 \%$ & $5.9 \%$ & 0.06 & 1.4 & 0.93 & 0.86 \\
Tea & $1690-1850$ & $13.6 \%$ & $10.8 \%$ & 0.155 & 0.67 & 0.97 & 0.88 \\
Coffee & $1690-1850$ & $1.6 \%$ & $1.6 \%$ & 0.126 & 0.98 & 0.99 & 0.85 \\
\cline { 3 - 4 } Welfare Gain & & $21.6 \%$ & $18.3 \%$ & & & & \\
\hline
\end{tabular}

Notes: $\mathrm{EV}$ refers to equivalent variation and $\mathrm{CV}$ to compensating variation. The parameter $\theta$ is the weight on utility from new good consumption, $\sigma$ is the elasticity of substitution, and $\nu$ is the new good utility shift. In order to ensure convergence of our estimation procedure, we set $\nu$ in the case of coffee to the same value as in the baseline calibration.

We find largely unchanged results for sugar and coffee, while tea now show larger gains. This is especially true for equivalent variation. Because the estimation procedure suggests that the elasticity of substitution is less than unity for tea, $v$ is also large. According to the results from the CES estimation, by 1850 at the lastest, there was simply no good alternative for tea in the eyes of Englishmen and -women.

\section{Alternative data series}

Next, we examine the robustness of our findings with respect to the data series used.

We use alternative price series, and also derive welfare gains for the case of combining sugar and tea into a single, composite commodity.

Clark's price series are not the only ones that can be used. Allen (1992) offers alternative series for sugar and tea. The data generally start later than the Clark series we use for our baseline estimates. Hence, the impact of new goods is bound to be lower - the initial, rapid fall in price, when gains in consumer surplus must have been largest, is not covered by the data.

Table 6 presents the results, and compares them with the baseline findings (for the full sample period). We use the value for $\rho$ calibrated from the joint estimation procedure. To show the impact of the data source separately, we also re-estimate the baseline specification with Clark data to match the date range in the Allen series. The Allen price data, using a shorter time period, gives only slightly lower welfare gains. For sugar, estimated from 1650 to 1850, equivalent variation falls from the baseline estimate of $8 \%$ to $5.3 \%$, while compensating variation remains essentially unchanged, declining from $7.6 \%$ to $7.2 \%$. If we compare this with the Clark data, but matched for the same time period, results are very similar. 
The welfare difference for tea is small as well, showing a small decline. CV is 6\% with the Allen data, instead of the $7.3 \%$ for the Clark data. EV for Allen's estimates implies a gain of 5.5\% instead of $7.9 \%$ from Clark. The implied budget shares derived from the results for the Allen dataset are quite large, amounting to over $15 \%$ of income spent on new goods. This is because the optimization procedure derives lower values for $\theta$. The Allen data imply a high value for the parameter $v-$ 0.44 for sugar, and 0.24 for tea. The $R^{2}$ values using the Allen data are also much lower than the Clark series- 0.55 for sugar and 0.41 for tea. It is because of these shortcomings, and the longer period covered, that we ultimately preferred the Clark series. Nonetheless, it is important that the overall size of welfare gains estimated is not affected by switching to the Allen dataset.

Table 6: Robustness - alternative data series

\begin{tabular}{cccccccc}
\hline \hline New Good & Year Range & $E V$ & $C V$ & $\nu$ & $\rho$ & $\theta$ & $R^{2}$ \\
\hline Baseline - Clark price data & & & & & & \\
Sugar & $1600-1850$ & $8.0 \%$ & $7.6 \%$ & 0.0993 & 0.9395 & 0.9435 & 0.8517 \\
Tea & $1690-1850$ & $7.9 \%$ & $7.3 \%$ & 0.0572 & 0.9395 & 0.9590 & 0.7718 \\
Clark - date range matched to Allen & & & & & \\
Sugar & $1650-1850$ & $7.7 \%$ & $7.4 \%$ & 0.1150 & 0.9395 & 0.8063 & 0.8134 \\
Tea & $1690-1850$ & $7.9 \%$ & $7.3 \%$ & 0.0572 & 0.9395 & 0.9590 & 0.7718 \\
Allen price data, $\rho=0.9395$ & & & & & & \\
$\quad \begin{array}{l}\text { Sugar } \\
\text { Tea }\end{array}$ & $1650-1850$ & $5.3 \%$ & $7.2 \%$ & 0.4348 & 0.9395 & 0.8984 & 0.5536 \\
& $1690-1850$ & $5.5 \%$ & $6.0 \%$ & 0.2441 & 0.9395 & 0.9410 & 0.4103 \\
\hline
\end{tabular}

Notes: The parameter values of $\nu$ and $\theta$ are calibrated by choosing values that minimize sum of squared error between predicted and actual new good consumption. EV refers to equivalent variation and CV to compensating variation. The parameter $\theta$ is the weight on utility from new good consumption, $\frac{1}{\rho}$ is the intertemporal elasticity of substitution, and $\nu$ is the new good utility shift.

In assessing the overall impact of new goods, we have until now proceeded as if it the welfare gains from individual goods are additive. This is not necessarily true. Our estimation and calibration procedure chooses parameter values that explain the rate of uptake of a new commodity, given a known path for its price and overall income.

However, assume that there is a second new good that is highly complementary to the consumption of the first new commodity. If the former declines sharply in price, takeup of the first new good may rise quickly, while its prices remains relatively high. We may therefore be overestimating the value that consumers attach to the new 
commodity. We would attribute the rapid rise in consumption to a strong preference, while it is really the decline in the complementary good's price that explains the takeoff in consumption. For the goods in question, the key question is if sugar and either coffee or tea were complementary to each other.

Table 7 gives the results for estimating welfare gains from sugar and tea jointly. The procedure used to estimate sugar and tea jointly is identical to the one used to estimate sugar, tea and coffee. Consumption is the sum of sugar and tea consumed in a given year, and we use as a price vector a Laspeyres price index with a base year of 1850. Even over the short period 1690-1850, using data on the consumption of sugar and tea jointly generates consistently larger estimates of welfare gains, using the preferred calibration of $\rho$. Compared to the baseline estimates, EV now rises from $12.4 \%$ to $16.8 \%$, and CV from 13.4 to $14.2 \%$.

Table 7: Robustness - sugar and tea estimated jointly

\begin{tabular}{|c|c|c|c|c|c|c|}
\hline New Good & $E V$ & $C V$ & $\nu$ & $\rho$ & $\theta$ & $R^{2}$ \\
\hline \multicolumn{7}{|c|}{ Sugar \& Tea Composite Good, 1690-1850 } \\
\hline$\rho=0.9395$ & $16.8 \%$ & $14.2 \%$ & 0.1075 & 0.9395 & 0.8984 & 0.8407 \\
\hline $0<\rho \leq 2$ & $19.1 \%$ & $15.6 \%$ & 0.1418 & 1.0705 & 0.9024 & 0.8433 \\
\hline \multicolumn{7}{|c|}{ Sugar, 1690-1850 } \\
\hline$\rho=0.9395$ & $4.6 \%$ & $6.1 \%$ & 0.4445 & 0.9395 & 0.9162 & 0.4178 \\
\hline $0<\rho \leq 2$ & $4.8 \%$ & $6.3 \%$ & 0.4685 & 0.9902 & 0.9226 & 0.4183 \\
\hline \multicolumn{7}{|c|}{ Tea, $1690-1850$} \\
\hline$\rho=0.9395$ & $7.9 \%$ & $7.3 \%$ & 0.0572 & 0.9395 & 0.9590 & 0.7718 \\
\hline $0<\rho \leq 2$ & $13.6 \%$ & $11.3 \%$ & 0.1550 & 1.4894 & 0.9711 & 0.8066 \\
\hline
\end{tabular}

Notes: $\mathrm{EV}$ refers to equivalent variation and $\mathrm{CV}$ to compensating variation. The parameter $\theta$ is the weight on utility from new good consumption, $\frac{1}{\rho}$ is the intertemporal elasticity of substitution, and $\nu$ is the new good utility shift.

\section{Correction for smuggling}

English consumers drank more tea and coffee, and used more sugar, as the price of these goods fell. The price decline was driven by four factors - lower tariffs, greater competition amongst producers, and improvements in production technology. As tariffs were cut, smuggling probably declined. Some of the measured increases in consumption may thus not be the result of consumers responding enthusiastically to small declines in the price of tea and the like. Instead, legal sales as a share of the 
whole may have increased. By using data on legal imports, we are effectively stacking the odds in favor of finding a large welfare gain.

To correct for this problem, we estimate the legal quantity of tea sold as a function of the price of tea, and the duty levied (details are presented in the Appendix). The corrected series gives higher predicted values than the official series for those periods with very high duties. The opposite is true of periods under moderate tariffs. For our calibration of welfare gains, we effectively abstract from the increases in 'legal' consumption that coincide with lower tariff rates. Based on the corrected series, we obtain estimates of EV (CV) of $11.4 \%(10.4 \%) .{ }^{38}$ Contrary to expectations, this is between one and two percentage points higher than under our baseline calculation. Much of the initial take-up of tea occurred in a context of high import duties.

\section{Comparison with alternative methods}

Hausman (1999) suggested a simple method for estimating welfare gains from the introduction of new goods:

$$
C V=\frac{1}{2} S \eta^{-1}
$$

where $\mathrm{CV}$ is the welfare gain measured in compensating variation, $\mathrm{S}$ is the share of the new good in expenditure, and $\eta$ is the price elasticity of demand. We use the estimates of price elasticities and budget shares from Horrell (1996), and combine this with the average budget share for her two benchmark sets of years 1787-1796 and 1830-1839. For sugar, tea, and coffee combined, we estimate a total gain (compensating variation) of $13.5 \%$ of expenditure. ${ }^{39}$ This is somewhat lower than the results reported above, under most scenarios, but it is broadly similar in overall magnitude - gains from colonial luxury goods were substantial, adding more than $10 \%$ to English living standards by the early nineteenth century. When we use the price elasticities estimated by Mokyr (1988), we obtain a very large effect for sugar, and a much smaller one for tea and coffee. ${ }^{40}$

\footnotetext{
${ }^{38}$ The predicted consumption of tea using our procedure is negative before 1720 . We set imports to zero before 1720 in the corrected series.

${ }^{39}$ We use the own-price elasticity for tea and coffee for sugar and treacle as well. This is because Horrell derives a questionable estimate of 0.48 for the latter, possibly because she is ignoring complementarities in the consumption of sugar and tea. Note that our figure is similar to the lower bound in Mokyr and O’Grada (1988), who use values ranging from -0.3 and -0.7 for tea and sugar. ${ }^{40}$ We use the results from his generalized inverse log specification. If used the estimates from the logistic function the implied CV would rise to 0.294 .
} 
Modern-day estimates of the demand elasticities suggest that these figures are plausible. Gemmill (1980), in a comprehensive survey of data from 73 countries, estimates the price elasticity of demand for sugar to be between -0.25 and -0.38 in the short run. Schmitz et al. (2008) argue that in the present-day US, $\eta=-0.14$.

Kanayama et al. (1999) estimate the demand elasticity for sugar to be between -0.13 and -0.16. In the most pessimistic case (using -0.45), we still obtain a welfare gain of 4 percent. For the highest contemporary estimates, the welfare gains range as high as 13 percent of household income. The highest absolute value of the elasticity found in modern-day studies in the case of sugar is the long-run elasticity estimated by Gemmill (1980). He found a figure of -0.45 . This would reduce the welfare gain for tea and coffee from 7 to 4 percent. Overall, we conclude that the orders of magnitude for welfare gains are robust to a wide range of alternative values for the calibration/ optimization exercise, data sources, and the use of an altogether different technique.

Table 8: Welfare Results using Hausman Methodology

\begin{tabular}{|c|c|c|c|c|}
\hline New Good & $S$ & $\eta$ & $C V$ & Source \\
\hline \multicolumn{5}{|c|}{ Historical elasticities } \\
\hline Tea \& coffee & $3.2 \%$ & -0.25 & $6.4 \%$ & Horrell 1996 \\
\hline Sugar \& treacle & $3.6 \%$ & -0.25 & $7.2 \%$ & Horrell 1996 \\
\hline Sum & 0.068 & & 0.135 & \\
\hline Tea \& coffee & $3.2 \%$ & -0.644 & $2.5 \%$ & Mokyr 1988 \\
\hline Sugar \& treacle & $3.6 \%$ & -0.099 & $1.8 \%$ & Mokyr 1988 \\
\hline Sum & 0.068 & & $20.7 \%$ & \\
\hline \multicolumn{5}{|c|}{ Contemporary elasticities } \\
\hline Tea \& coffee & $3.2 \%$ & -0.22 & $7.3 \%$ & Cramer 1973 \\
\hline Sugar \& treacle & $3.6 \%$ & -0.14 & $12.9 \%$ & Schmitz et al. 2008 \\
\hline Sugar \& treacle & $3.6 \%$ & -0.13 to -0.16 & 11.3 to $13.8 \%$ & Kanayama 1999 \\
\hline Sugar \& treacle & $3.6 \%$ & -0.25 to -0.45 & 4 to $7 \%$ & Gemmill 1980 \\
\hline
\end{tabular}

\section{Conclusions}

There is a broad consensus that living standards stagnated for millennia before the transition from "Malthus to Solow" (Hansen and Prescott 2002, Galor 2005). Clark (2007) concluded that Englishmen in 1800 lived no better than their ancestors on the 
African savannahs. Long-run wage series suggest that life in England under Queen Victoria was hardly better than it had been under Henry VIII. ${ }^{41}$ We argue that stagnating long-run real wage indices largely reflect measurement error. Life in early modern Britain got better - much better. Standard real wage series simply divide the nominal wage by the price of an unchanging consumption basket. ${ }^{42}$ This is inappropriate for the period after the Discovery of America. By the eighteenth century at the latest, consumption habits had undergone a profound transformation. New goods provided variety where monotony had reigned. We use recently-developed methods to estimate the value of these gains, and argue that they are substantial adding at least the equivalent of $16 \%$ (and possibly as much as $20 \%$ ) of household income to welfare.

By the end of the early modern period, breakfast had changed from porridge and cold meat consumed with beer, to the morning meal we still consume today bread or pastry, combined with a sugary hot beverage full of caffeine. These changes have been highlighted by social historians (Schivelbusch 1992; Braudel 1988; Mintz 1985). Consumption of overseas ‘small luxuries’ spread relatively quickly.

Consumers voted with their pocketbooks in favor of these goods. Initially, high prices stood in the way of rapid adoption. As soon as cheaper supplies became available, consumption surged. By the $18^{\text {th }}$ century, the regular use of tea and coffee had spread to all strata of society. Sugar was the second-biggest import of the UK by value in 1850, after cotton, and ahead of all grain including wheat. Tea was fourth, and coffee, sixth. Even the poorest groups of society spent 6-7\% of household income on these colonial goods.

These results suggest that existing real wage indices for early modern Europe may be much too pessimistic. In many European countries - with the exception of England and the Netherlands - wages came under pressure as population rose after 1500. Allen (2001) documents the extent to which nominal incomes bought ever less in terms of a constant consumption basket. Our findings suggest that much of the decline in early modern living standards may be more to do with mis-measurement than with immiseration. Consumption baskets typically used in studies of changes of living standards after 1500 give a weight of 50\% to bread and beer (Allen 2001), and

\footnotetext{
${ }^{41}$ Clark (2005).

${ }^{42}$ Even where new goods are eventually incorporated in the consumption basket, the welfare gains from their introduction will be largely overlooked if this occurs at a relatively late stage of adoption.
} 
none to new colonial goods. It is therefore not surprising that many authors find Malthusian stagnation before 1800 (Clark 2007). We argue that this reflects difficulties of measurement, and not an absence of genuine improvements in the quality of life. Living standards improved by “stealth”. Traditional real wage indices have missed these changes because they are not designed to measure the impact of new goods. These findings also have implications for the period of the Industrial Revolution. While sugar, tea, and coffee were no longer "new”, their use spread far more widely -- and even Engels had to concede that tea was an integral part of lower class consumption patterns in England. The latest estimates by Clark (2005) and Allen (2007) suggest that real incomes probably increased by no more than $40-50 \%$ between 1780 and 1850. Our findings suggest that this is too pessimistic. Increases in consumer welfare by 1850 from the availability of coffee, tea, and tobacco, as derived from the Greenwood-Kopecky and alternative methods, are substantial. ${ }^{43}$

Our results for tea, sugar, and coffee constitute a lower bound on the discoveries' overall effect. They stand pars pro toto for a wider range of 'new goods' that arrived on European shores as a result of overseas expansion. The addition of tomatoes, potatoes, exotic spices, polenta, and tobacco transformed consumption habits in even more fundamental ways than sugar, tea, and coffee did. If the rise in consumption of all of these colonial goods was measured accurately, welfare gains for European consumers after 1492 would have been even larger than our findings suggest.

\footnotetext{
${ }^{43}$ Ideally, we would calculate welfare gains for the equivalent period, 1780-1850. Since the method relies on the assumption that the good is "new", and hardly consumed in the beginning, this is not strictly possible for the goods discussed here. It is certainly possible for a different set of goods that entered the English consumption basket after 1780.

${ }^{45}$ The second reason is that adoption took place over a much longer period - hundreds of years. Yet even if we restrict ourselves to the period up to 1750, we find welfare gains for coffee, tea and sugar of $3-4 \%$, equal to the gains from computers estimated by Greenwood and Kopecky. By 1790, the gains from tea alone had reached a level of $7 \%$.
} 
Table 9: Impact of new goods on welfare

\begin{tabular}{lccc}
\hline \hline Good & Welfare Gain & Year & Source \\
\hline Modern Goods & & & \\
Apple Cinnamon Cheerios & $0.002 \%$ & 1992 & Hausman (1996) \\
Personal computers & $3.5-4 \%$ & 2004 & Kopecky \& Greenwood (2009) \\
Minivans & $0.03 \%$ & 1988 & Petrin (2002) \\
Satellite TV & $0.04-0.06 \%$ & 2001 & Goolsbee \& Petrin (2004) \\
Internet & $2-3 * \%$ & 2005 & Goolsbee \& Klenow (2006) \\
Mobile phones & $0.46-0.9 \%$ & 1996 & Hausman (1999) \\
& & & \\
Colonial Luxuries & & & this study \\
Sugar & $7.58-8.03 \%$ & $1600-1850$ & this study \\
Tea & $7.28-7.85 \%$ & $1690-1850$ & this study \\
Coffee & $1.45-1.54 \%$ & $1690-1850$ & \\
\hline
\end{tabular}

Notes: Welfare results from this study are generated using Clark data with preferred $\rho$ calibration.

* for linearization case.

Compared to the introduction of new goods today, the welfare gains from introducing goods in the past were large. In Table 9, we compare the impact of recently invented new goods with our results. Even for the single biggest items, such as personal computers and the internet, welfare gains (while substantial) pale compared to historical precedent. Hausman (1996) estimated the rise in consumer surplus from the introduction of Apple Cheerios as $0.002 \%$ of consumption expenditure. Goolsbee and Klenow (2006) derive a gain of approximately 2\% for the internet. For the good with the biggest estimate, personal computers, Greenwood and Kopecky (2009) show gains equivalent to $3.5-4 \%$ of income. Compared to these results, our findings suggest welfare gains that are orders of magnitude larger compared to all modern goods (except personal computers).

In the past, introducing a new good mattered more - welfare gains were bigger, because the pre-existing range of goods was smaller than it is today. ${ }^{45}$ Put another way - adding Apple Cheerios to the range of choices for breakfast cereals may improve welfare. However, being able to replace beer soup, porridge and cold cuts with milky, sugary coffee and bread with jam was much nicer. Exotic new goods from the Americas and the Far East - pepper and nutmeg, tea and sugar, coffee and tobacco, chocolate and cloves - improved living standards by far more than modern consumers, sated by an ever-expanding range of new goods, can readily appreciate. The reason why seemingly mundane goods like sugar, coffee and tea made a big 
difference to living standards is that life was not just 'nasty, brutish, and short' in Hobbes phrase at their time of introduction - it was also (at least in culinary terms) grey, boring, and bland. 


\section{References:}

Acemoglu, Daron, Simon Johnson, and James Robinson (2005) “The Rise Of Europe: Atlantic Trade, Institutional Change, And Economic Growth.” American Economic Review, 95:546-579.

Allen, Robert C. (1992). Enclosure and the Yeoman. New York: Oxford Press.

Allen, Robert C. (2001). "The Great Divergence in European Wages and Prices from the Middle Ages to the First World War.” Explorations in Economic History 38(4): 411-447.

Allen, Robert C. (2007). “Engel’s Pause: A Pessimist’s Guide to the British Industrial Revolution”, Nuffield working paper.

Berry, Steven, James Levinsohn, and Ariel Pakes (1995). “Automobile Prices in Market Equilibrium”, Econometrica 63(4): 841-90.

Bentley, J. H. (1999). “Asia in World History,” Education About Asia 4: 5-9.

Braudel, Fernand (1988). The Structures of Everyday Life. London: Phoenix.

Bresnahan, Tim F (1997). "The Apple-Cinnamon Cheerios War: Valuing New Goods, Identifying Market Power, and Economic Measurement”. Available at http://www.stanford.edu/ tbres/

Bresnahan, Tim F. and R. J. Gordon (1996). "The Economics of New Goods: Introduction” In The Economics of New Products, eds., T. Bresnahan and R. Gordon, Chicago: University of Chicago Press: 1-26

Broda, Christian, and David Weinstein (2006). "Globalization and the Gains from Variety”, Quarterly Journal of Economics 121(2): 541-85.

Brynjolfsson, Erik, Hu, Yu Jeffrey and Michael Smith (2003). “Consumer Surplus in the Digital Economy: Estimating the Value of Increased Product Variety at Online Booksellers”. MIT Sloan Working Paper No. 4305-03.

Cheung, Hoh and Lorna Mui (1975). "Trends in Eighteenth-Century Smuggling Reconsidered” Economic History Review 28(1): 28-43.

Clark, Gregory, Kevin H. O'Rourke and Alan M. Taylor (2008). "Made in America? The New World, the Old, and the Industrial Revolution,” NBER Working Papers 14077.

Clark, Gregory (2007). "The Long March of History: Farm Wages, Population and Economic Growth, England 1209-1869.” Economic History Review 60(1): 97-136.

Clark, Gregory (2004). “The Price History of English Agriculture, 1209-1914.” Research in Economic History 22: 41-124.

Clark, Gregory (2005) “The Condition of the Working Class in England, 1209-2004.” Journal of Political Economy 113 (6): 707-36.

Clark, Gregory and Ysbrand Van Der Werf (1998). "Work in Progress? The Industrious Revolution.” The Journal of Economic History 58(3): 830-843.

Cole, W. A. (1958). “Trends in Eighteenth-Century Smuggling.” Economic History Review 10(3): 395-410. 
Cole, W. A. (1975). "The Arithmetic of Eighteenth-Century Smuggling: Rejoinder” Economic History Review 28(1): 44-49.

Cowan, Brian (2005). The Social Life of Coffee: The Emergence of the British Coffeehouse, New Haven: Yale University Press.

DeVries, Jan (2008). The Industrious Revolution: Consumer Behavior and the Household Economy, 1650 to the Present. Cambridge: Cambridge University Press.

Davis, Ralph (1979). The Industrial Revolution and British Oversas Trade. Leicester: Leicester University Press.

Deerr, Noel (1950). History of Sugar. London: Chapman \& Hall.

Dixit, Avinash K. and Joseph E. Stiglitz (1977). "Monopolistic Competition and. Optimum Product Diversity.” American Economic Review 67(3): 297-308.

Eden, Sir Frederick (1797). The State of the Poor. London.

Engels, Friedrich (1844). The Condition of the Working Class in England. New York: Penguin Classics, 1987.

Feenstra, Robert C. (1994). "New Product Varieties and the Measurement of International Prices.” American Economic Review 84(1): 157-77.

Feinstein, Charles H. (1998). "Pessimism Perpetuated: Real Wages and the Standard of Living in Britain during and after the Industrial Revolution.” Journal of Economic History 58(3): 625-58.

Fogel, Robert F. (1994). "Economic Growth, Population Theory, and Physiology: The Bearing of Long-Term Processes on the Making of Economic Policy.” American Economic Review 84(3): 369-95.

Forrest, Denys (1973). Tea for the British, London: Chatto \& Windus.

Frank, Andre Gunder (1998). ReOrient: Global Economy in the Asian Age. Berkeley, CA: University of California Press.

Galor, Oded (2005). “From Stagnation to Growth: Unified Growth Theory”, in Philip Aghion and Steven Durlauf, eds., Handbook of Economic Growth, Vol. 1A.

Amsterdam: North-Holland.

Galor, Oded and Omer Moav (2002). "Natural Selection and the Origins of Economic Growth.” Quarterly Journal of Economics 117(4): 1133-1192.

Galor, Oded and David Weil (2000). "Population, Technology and Growth: From Malthusian Stagnation to Demographic Transition and Beyond.” American Economic Review 90(4): 806-28.

Gemmill, Gordon (1980). "Form of Function, Taste, and the Demand for Sugar in Seventy-Three Nations”, European Economic Review 13: 189-205.

Goodman, Jordan (1995). "Excitantia: or, How Enlightenment Europe Took to Soft Drugs”, in: Jordan Goodman, P. E. Lovejoy and Andrew Sherratt (eds.), Consuming Habits: Drugs in History and Anthropology. London.

Goolsbee, Austan, and Peter J. Klenow (2006). "Valuing Consumer Products by the Time Spent Using Them: An Application to the Internet.” American Economic Review 96(2): 108-113. 
Goolsbee, Austan and Amil Petrin (2004). "The Consumer Gains from Direct Broadcast Satellites and the Competition with Cable TV.” Econometrica 72: 351-381

Greenwood, Jeremy and Kopecky, Karen A. (2009). "Measuring the Welfare Gain from Personal Computers.” Economie d'avant garde Research Report No. 15.

Hansen, Gary D., and Edward C. Prescott (2002). "Malthus to Solow.” American Economic Review, 92 (4): 1205-1217.

Hausman, Jerry (1996). "Valuation of New Goods Under Perfect and Imperfect Competition.” In The Economics of New Products, eds., T. Bresnahan and R. Gordon, Chicago: University of Chicago Press: 209-237.

Hausman, Jerry (1999). “Cellular Telephone, New Products, and the CPI.” Journal of Business and Economic Statistics 17(2): 188-194.

Horrell, Sara (1996). “Home Demand and British Industrialization.” Journal of Economic History 56 (3): 561-604.

Hotelling, H. (1929). “Stability in Competition,” Economic Journal 39: 41-57.

Hulten, Charles (1996). “Comment” In The Economics of New Products, eds., T. Bresnahan and R. Gordon, Chicago: University of Chicago Press: 66-70.

Jones, Chad (2001). "Was an Industrial Revolution Inevitable?” Advances in Macroeconomics 1(2).

Kanayama, Toshihisa, Caldas, Eduardo, Manabu Sawada, and Tokihisa Doi (1999). “A Study on Changes in the Demand for Sugar and the Sugar Industry in Japan”, Obihiro University of Agriculture and Veterinary Medicine wp.

Kremer, Michael (1993). "Population Growth and Technological Change: One Million B.C. to 1990.” Quarterly Journal of Economics 108: 681-716.

Lancaster, K.J. (1975). “Socially Optimal Product Differentiation.” American Economic Review 65(4): 567-585.

Lindert, Peter H., and Jeffrey G. Williamson (1983) “English Workers’ Living Standard During the Industrial Revolution: A New Look.” Economic History Review 36: $1-25$.

Lindert, Peter H. and Jeffrey G. Williamson (1985). “English Workers’ Real Wages: Reply to Crafts,” Journal of Economic History 45: 145-153.

Loschky, D. (1980). "Seven Centuries of Real Income per Wage Earner Reconsidered”, Economica 47: 459-465.

Maddison, Angus (2001). The World Economy: A Millennial Perspective, Paris: OECD.

Menard, Russell (1991). “Transport Costs and Long-range Trade: Was there a European ‘Transport Revolution’ in the Early Modern Era?”. In: J. D. Tracy (ed.), Political Economy of Merchant Empires. Cambridge: Cambridge University Press.

Mintz, Sidney W. (1985). Sweetness and Power: The Place of Sugar in Modern History. New York: Viking Penguin.

Mitchell, B. R. and P. Deane (1962). Abstract of British Historical Statistics Cambridge. 
Mokyr, Joel (1988). "Is There Still Life in the Pessimist Case? Consumption during the Industrial Revolution, 1790-1850.” Journal of Economic History 48(1): 69-92.

Mokyr, J., and C. Ó Grada (1988). "Poor and Getting Poorer?: Living Standards in Ireland. Before the Famine,” Economic History Review, 41:209-35.

Nordhaus, William D. (1996). "Do Real-Output and Real-Wage Measures Capture Reality? The History of Lighting Suggests Not”, In The Economics of New Products, eds., T. Bresnahan and R. Gordon, Chicago: University of Chicago Press, 27 - 70.

Nunn, Nathan, and Nancy Qian (2008). “Columbus’s Contribution to World Population and Urbanization: A Natural Experiment Examining the Introduction of Potatoes," mimeo, Harvard University.

O’Brien, Patrick (1982). “European Economic Development: The Contribution of the Periphery”, Economic History Review 34 (1): 1-18.

O’Rourke, Kevin and Jeffrey Williamson (2002). "When Did Globalization Begin?”, European Review of Economic History 6: 23-50.

Pepys, Samuel (1854). Diary and Correspondence of Samuel Pepys, F.R.S. Hurst and Blackett.

Petrin, Amil (2002). "Quantifying the Benefits of New Products: The Case of the Minivan.” Journal of Political Economy, 110(4): 705-729.

Phelps Brown, Henry and Sheila V. Hopkins (1981). A Perspective of Wage and Prices. London: Methuen.

Romer, Paul M. (1994), "New Goods, Old Theory, and the Welfare Costs of Trade Restrictions.” Journal of Development Economics 43(1): 5-38.

Schivelbusch, Wolfgang (1992). Tastes of Paradise: A Social History of Spices, Stimulants, and Intoxicants. Trans. David Jacobson NY: Vintage.

Shamas, Carole (1990). The Pre-industrial Consumer in England and America. Oxford: OUP.

Schmitz, Andrew, Schmitz, Troy, and James Seale (2008) , “CAFTA and US Sugar”, University of Florida Research Report.

Spence, Michael (1976). "Product Differentiation and Welfare," American Economic Review, American Economic Association, 66: 407-14.

Vanderlint, Jacob. (1734) 1914. Money Answers All Things. Edited by Jacob H. Hollander. Baltimore: Johns Hopkins University Press.

Voigtlaender, Nico and Hans-Joachim Voth (2006). "Why England? Demographics, Living Standards and the First Industrial Revolution.” Journal of Economic Growth 11(4): 319-61.

Voth, Hans-Joachim (2001). Time and Work in England, 1750-1830. Oxford: Oxford University Press.

Wallerstein, Immanuel (1974). The Modern World-System, vol. I: Capitalist Agriculture and the Origins of the European World-Economy in the Sixteenth Century. San Diego, CA: Academic Press. 
Wrigley, E.A., Ruth Davies, Jim Oeppen, and Roger Schofield (1997). English

Population History from Family Reconstitution. Cambridge: Cambridge University Press. 


\section{Appendix}

We briefly set out our methodology for correcting the quantity of tea consumed in Britain for the effect of smuggling. Figure A1 demonstrates the problem - legal imports jump around the date of the big duty reduction. To eliminate the effects of tariff changes, we estimate

$Q_{t}=C+\beta p_{t}+\gamma D_{t}+\varepsilon_{t}$

where $\mathrm{Q}$ is the (legal) quantity of tea imported, $\mathrm{p}$ is the retail price, $\mathrm{D}$ is the duty charged on tea imports, and $\varepsilon$ is the error term. Since naval wars and weather events were responsible for most of the short-term variation in prices, we think of this basic relationship as tracing out the (short-term) demand curve. By adding a control for the tariff, we incorporate information about incentives to smuggle. Estimating eq. A1 yields coefficient (t-statistic) estimates for C, $\beta$, and $\gamma$ of 3.05 [25.9], -0.008 [13.7], and -0.008 [5.8]. This suggests that years with high imports were on average associated with low retail prices. Over and above the effect from low retail prices, lower duty charged also coincides with greater imports. ${ }^{46}$

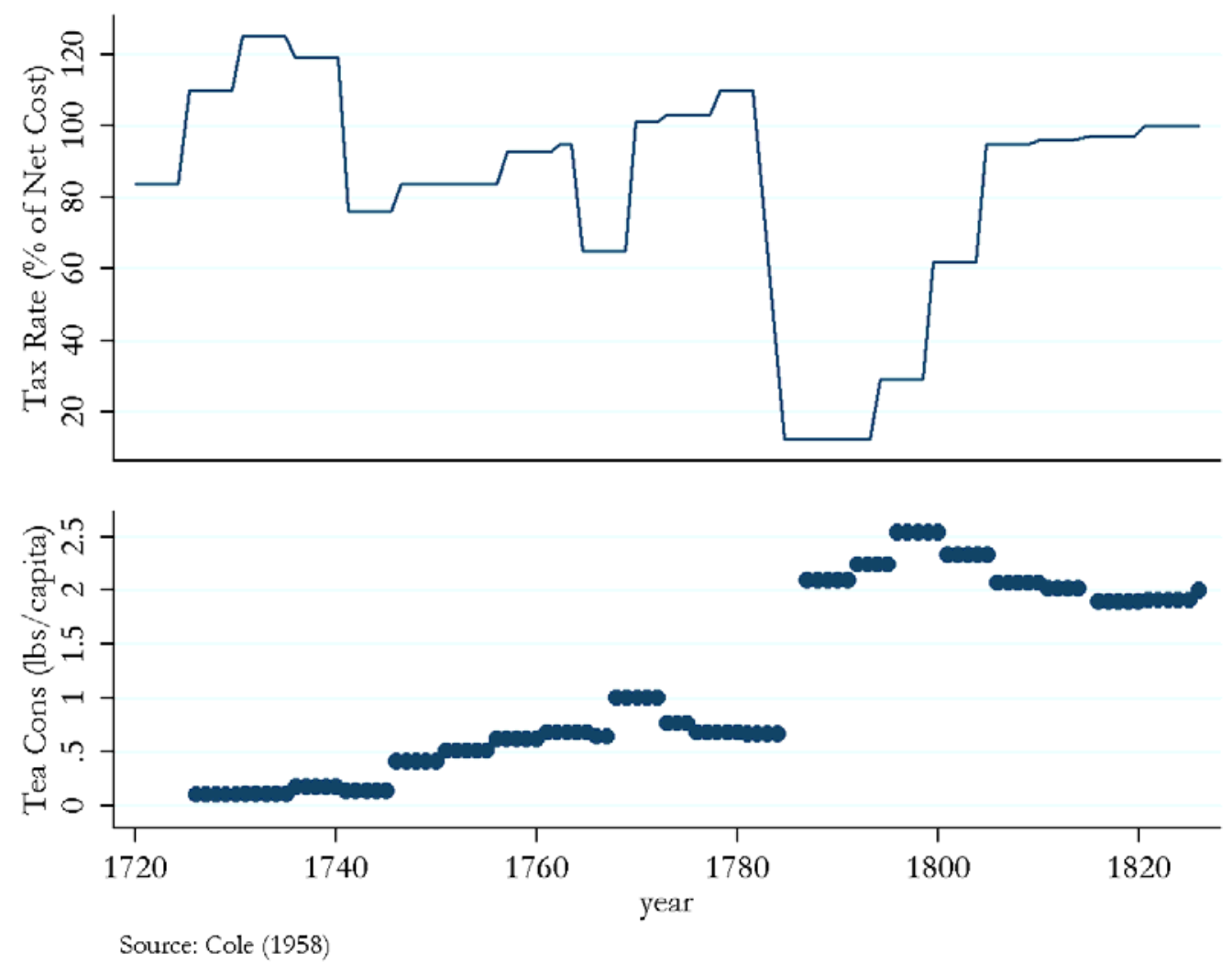

Figure A1

\footnotetext{
${ }^{46}$ To the extent that the regression picks up a common trend, we will be overcorrecting for smuggling, thus biasing results against our claim that new goods added substantially to welfare.
} 
To adjust for the effect of smuggling, we want to know how large total imports would have been had it not been for a (time-varying) incentive to smuggle. To calculate a constant-smuggle import series for tea, we hold the tariff rate constant at the period average. We then use the estimated relationship from A1 to predict tea demand in the absence of tariff changes. This effectively reduces the rate of growth in the British demand for tea. Adjusted tea imports in the (early) years of our sample are now markedly higher. Figure A1 illustrates the change. During the period of the highest tariffs, the middle of the $18^{\text {th }}$ century, there is substantial divergence between the corrected and uncorrected series. Then, as tariffs are cut drastically after 1784, the predicted series falls below the 'legal' import series. Overall, the variability of the new, predicted series is lower than of the official imports.

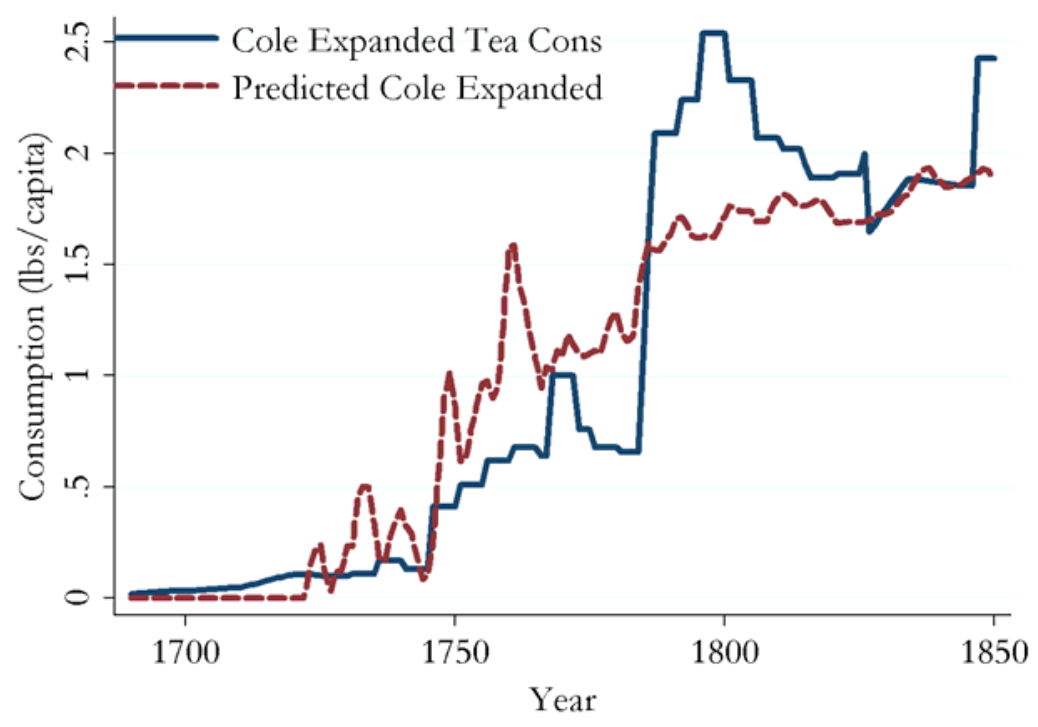

Figure A2 